\title{
THE THEORETICAL CALCULATIONS AND EXPERIMENTAL MEASUREMENTS OF ACID DISSOCIATION CONSTANT AND THERMODYNAMIC PROPERTIES OF GLYCYL-ASPARTIC ACID IN AQUEOUS SOLUTION AT DIFFERENT TEMPERATURES
}

\author{
FATEMEH ZABIHI ${ }^{1}$, FARHOUSH KIANI $^{2 *}$, MOJTABA YAGHOBI ${ }^{1}$, SEYED AHMAD SHAHIDI ${ }^{3}$ \\ AND FARDAD KOOHYAR ${ }^{4,5^{*}}$ \\ ${ }^{I}$ Department of Physic, Faculty of Science, Ayatollah Amoli Branch, Islamic Azad University, Amol, Iran. \\ ${ }^{2}$ Department of Chemistry, Faculty of Science, Ayatollah Amoli Branch, Islamic Azad University, Amol, Iran. \\ ${ }^{3}$ Department of Food Science and Technology, College of Agriculture and Food Science, Ayatollah Amoli Branch, Islamic Azad University, Amol, Iran. \\ ${ }^{4}$ Division of Computational Physics, Institute for Computational Science, Ton Duc Thang University, Ho Chi Minh City, Vietnam. \\ ${ }^{5}$ Faculty of Applied Sciences, Ton Duc Thang University, Ho Chi Minh City, Vietnam.
}

\begin{abstract}
In this research work, a potentiometric technic was used to measure the acidic dissociate constants $\left(\mathrm{pK}_{\mathrm{a}}, \mathrm{s}\right)$ for glycyl aspartic acid (GLY-ASP) at temperatures (298.15, 303.15, 313.15, and 318.15) $\mathrm{K}$ and in $0.1 \mathrm{~mol} / \mathrm{l}$ ionic strength of chloride sodium. Using this data, we calculated the thermodynamic properties (changes of enthalpy, $\Delta H$, changes of entropy, $\Delta S$, and changes of Gibbs free energy, $\Delta G$ ) for acidic dissociation reaction of GLY-ASP. All analyses of data were studied in $\mathrm{pH}=1.5-11$ and in the aqueous solution. In addition, the value of the acid dissociation constants $\left(\mathrm{pK}_{\mathrm{a} 1}, \mathrm{pK}_{\mathrm{a} 2}\right.$, and $\left.\mathrm{pK}_{\mathrm{a} 3}\right)$, the optimized structure, and the thermodynamic properties of GLY-ASP were calculated in aqueous solution at various temperatures by ab initio and DFT methods. Density function theory (DFT) has been used based on the B3LYP/6-31+G(d) theory to explain the obtained acid dissociation constants of GLY-ASP as well as interactions between solvent and solvated cation, anion, and neutral species of GLY-ASP. Thomasi's method was used to analyze the formation of intermolecular hydrogen bonding between the water molecule and various species of GLY-ASP. In addition, the energy gap of anionic, cationic, and neutral species of GLY-ASP were obtained for dissociation reactions of GLY-ASP. Finally, for GLY-ASP, the theoretically calculated and experimentally determined $\mathrm{pK}_{\mathrm{a}}, \mathrm{s}$ were compared together and a good agreement was observed between them in the first, second, and third ionization constant of GLY-ASP.
\end{abstract}

Keywords: Glycyl aspartic acid; acid dissociation constant; thermodynamic properties; density function theory; Ab initio.

\section{INTRODUCTION}

Amino acids are molecules which have an amine group $\left(-\mathrm{NH}_{2}\right)$, and a carboxylic group $\left(-\mathrm{CO}_{2} \mathrm{H}\right)$. Whenever two or more amino acids are connected together, they make a peptide. Peptides are identified from proteins based on the size [1,2]. The difference among peptides is based on the residuals of amino acids in each molecule. According to this fact, they are classified as a dipeptide, tripeptide, and so on.<smiles>[NH3+]CC(=O)NC(CC(=O)O)C(=O)O</smiles>
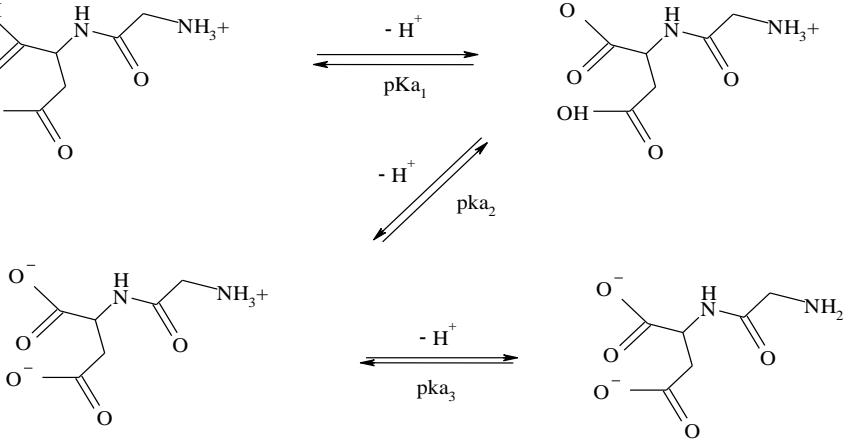

Figure 1. Suggested protonation processes of GLY-ASP.

In the last decade, the structural properties of different peptides have been investigated by many researchers. These data are used in biotechnology, medicine, drug synthesis, food supplements, and analgesic toxins $[3,4]$. The shortest peptides are dipeptides, including two amino acids that are joined together by one simple peptide bonding. As it can be seen in Figure 1, GLY-ASP is a dipeptide which has one carboxyl group, in low $\mathrm{pH}$ in acidic status, one another carboxyl group, in ordinary $\mathrm{pH}$ between acid and alkaline status, and an amine group in high $\mathrm{pH}$ in alkaline status.

Acidic dissociation constant $\left(\mathrm{pK}_{\mathrm{a}}\right)$ for different species of amino acids and dipeptides were studied in the recent years $[5,6]$. The $\mathrm{pK}_{\mathrm{a}}$ is used for determining solubility and permeability of solutions in the environmental and pharmaceutical fields [7-9]. There are various experimental techniques to measure acidic dissociation constant such as HPLC, potentiometer, and spectrophotometry
[10-14]. To determine the physiochemical properties of a substance, first it must be solved in a solvent. Therefore, it is essential to measure the solubility of a substance in special solvent at different temperatures and various ionic strengths which can describe the thermodynamic system of solution, such as enthalpy and entropy changes of dissolving processes.

One of the most important physical and chemical factors of micro- and macromolecules is the acid dissociation constant, generally known as $\mathrm{pK}_{\mathrm{a}}$. In the present study, the acid dissociation constant was determined for GLY-ASP, in water, by a potentiometric technique. Potentiometric technique is useful and reliable method to measure auto-proteolysis and dissociation constant of various solvents and solutions. In this technique, a glass electrode is used to measure $\mathrm{pH}$ and reaction potential in each step. In potentiometry, information about a sample composition is obtained through the appeared potential between two electrodes. Nowadays, selected potentiometric electrodes are used in many fields of clinical diagnosis, industrial processes control, environmental studies, and physiology. This technique is quick, cheap, and accurate [15]. In recent years, many researchers have tried to theoretically calculate the acid dissociate constant of different molecules by Ab initio and DFT methods [16,17]. Considerable research has been carried out to calculate the acid dissociation constants in the gas phase, but there is lack of research in the calculation of acidity in the solution phase [18].

The $\mathrm{pK}_{\mathrm{a}}$ is a criterion for measuring the strength of an acid or alkaline. The $\mathrm{pK}_{\mathrm{a}}$ equals to negative logarithm of equilibrium constant $\left(K_{\mathrm{a}}\right)$ of a neutral or charged form of a molecule by which the various species charge across various $\mathrm{pH}$,s. A weak acid has a relative $\mathrm{pK}_{\mathrm{a}}$ between 2 and 12 . Acids with $\mathrm{pK}_{\mathrm{a}}$ values lower than 2 are strong acids [19]. Acid equilibrium constants $\left(\mathrm{K}_{\mathrm{a}}, \mathrm{pK}_{\mathrm{a}}=-\log \mathrm{K}_{\mathrm{a}}\right)$ are an important property of organic compounds with extensive effects on many biological and chemical systems. This parameter is an important factor in the pharmacokinetics of drugs and the interactions of proteins with other molecules [20].

In this research work, the values of the acid dissociation constant $\left(\mathrm{pK}_{\mathrm{a} 1}, \mathrm{pK}_{\mathrm{a} 2}\right.$, and $\left.\mathrm{pK}_{\mathrm{a} 3}\right)$, the thermodynamic properties $(\Delta H, \Delta S$, and $\Delta G)$ and optimized structure of GLY-ASP have been calculated in the aqueous solution at various temperatures by potentiometric, Ab initio and DFT methods. Density function theory (DFT) was used based on the B3LYP/6-31+G(d) theory to explain the obtained acid dissociation constants of GLY-ASP and also interactions between solvent and dissolved cationic, anionic, and neutral species of GLY-ASP. 
Thomasi's method was used to analyze the formation of intermolecular hydrogen bonding (IHB) between the water molecule and various species of GLY-ASP. In addition, the energy gap of anionic, cationic, and neutral species of GLY-ASP were obtained for the dissociation reactions of GLY-ASP. Finally, the ionization potential was calculated from $\mathrm{I}=-\mathrm{E}_{\mathrm{HOMO}}$ while the electron affinity was determined from $\mathrm{A}=-\mathrm{E}_{\mathrm{LUMO}}[21]$

\section{RESEARCH METHODOLOGY}

\subsection{Experimental process}

\subsubsection{Chemicals}

GLY-ASP $\left(\mathrm{C}_{6} \mathrm{H}_{10} \mathrm{~N}_{2} \mathrm{O}_{5}\right)$ was purchased from Sigma-Aldrich. $\mathrm{NaCl}, \mathrm{NaOH}$, and $\mathrm{HCl}$ were purchased from Merck Company. The purity of GLY-ASP was $99 \%$. Also, the purity of $\mathrm{NaCl}, \mathrm{NaOH}$, and $\mathrm{HCl}$ was $98 \%$. These components were used without further purification. Double distilled water was used to prepare samples for this research.

\subsubsection{Apparatus}

The electromotive force, E, was measured using a Metrohm model $781 \mathrm{pH}$ ionmeter research potentiometer equipped with a combined $\mathrm{pH}$ electrode which consisted of a glass electrode and a reference $\mathrm{Ag} / \mathrm{AgCl}$ electrode built into a single chamber. The combined glass-pH electrode (model 6.0258.000) was modified by replacing its aqueous $\mathrm{KCl}$ solution with 0.01 mol.dm ${ }^{-3} \mathrm{NaCl}$ and 0.09 mol. $\mathrm{dm}^{-3} \mathrm{NaClO}_{4}$ saturated with $\mathrm{AgCl}$. The electrode was soaked for 15 to 20 minutes in a water-alcohol mixture before the potentiometric measurements.

\subsubsection{Procedure}

All titrations were carried out in an $80 \mathrm{~cm}^{3}$ thermostated, double walled glass vessel. Potentiometric titration method (with $1 \mathrm{M} \mathrm{NaOH}$ and $0.1 \mathrm{M} \mathrm{HCl}$ ) was used to determine the protonation constants. All tests were conducted in $0.1 \mathrm{~mol} / \mathrm{l}$ ionic strength of $\mathrm{NaCl}$ at $\mathrm{T}=298.15 \mathrm{~K}$ to $318.15 \mathrm{~K}$. Analyte and titrant solutions were prepared to calculate protonation constants in the following manner:

Analyte solution: $2 \mathrm{ml} \mathrm{HCl} 0.1 \mathrm{M}$ with $2 \mathrm{ml} \mathrm{NaCl} 1 \mathrm{M}$ was reached $20 \mathrm{ml}$ volume using distilled water; a certain amount of the weighted GLY-ASP was added to it later.

Alkaline titrant solution: $2 \mathrm{ml} \mathrm{NaOH} 1 \mathrm{M}$ with $2 \mathrm{ml} \mathrm{NaCl} 1 \mathrm{M}$ was reached 20 $\mathrm{ml}$ by distilled water.

$\mathrm{NaCl}$ was used for titration in certain ionic strength. The titration was done in $\mathrm{pH}=1.5$ to 11 . A magnet was put in the dish for better homogenization and then the glass electrode was calibrated by the present buffers and put in the solution. After taht, we added the titrant solution to the analyte solution (0.05 to 0.05$)$ for calibration. The calibration of the instrument was done by the Nernst eq in Excel program. An amount of the weighted GLY-ASP was added to the analyte solution and titration was continued by adding a certain amount of titrant by micropipette. Potential was read each time by the Metrohm model $781 \mathrm{pH}$ ionmeter. All tests were individually conducted at $\mathrm{T}=298.15 \mathrm{~K}$ to $318.15 \mathrm{~K}$.

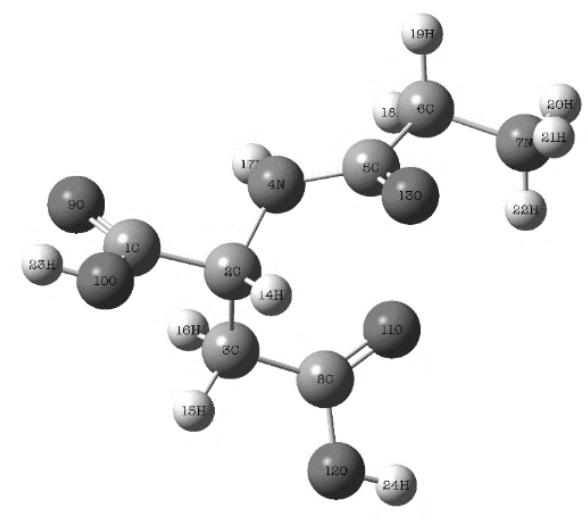

Figure 2. Optimized structure of GLY-ASP cation for performing the calculations.

\subsection{Theoretical calculations}

Figure 2 shows the optimized structure of cation specie of GLY-ASP. This structure was drawn by the semi-experimental $\mathrm{PM}_{3}$ method using program Hyperchem version 8.0.8 for Windows. All calculations and optimization about studied species of GLY-ASP were done using the GAUSSIAN 98 program. DFT calculations were done using the hybrid exchange-correlation function and the Gaussian B3LYP/6-31+G(d) basis set [22-24]. The Polar Constellation Model (PMC) was used to analyze solvent (water) effects on all the involved samples in ionization reaction which generate hydrogen bonds with water molecules [2527]. All reactions of various species of GLY-ASP were examined in an excel file and reactions with more errors, in $\mathrm{pK}_{\mathrm{a}}$ values, were deleted. Finally, the suitable reactions for the first, second, and third ionization processes of GLY-ASP were selected. All calculations were carried out at $\mathrm{T}=298.15 \mathrm{~K}$ to $318.15 \mathrm{~K}$.

\section{RESULTS AND DISCUSSION}

\subsection{Experimental results and discussion}

In this article, the values of $E_{\mathrm{a}}^{\prime}$ and $K$ were obtained using potentiometric calibration. The electric electrodes potential, $E$, can be written as the eq:

$E=E^{\circ}+k \log \left[\mathrm{H}^{+}\right]+k \log \gamma_{\mathrm{H}+}+E_{\mathrm{LJ}}$

In eq $1, E^{\circ}, E_{\mathrm{LJ}}, k$, and $\gamma_{\mathrm{H}^{+}}$show standard potentials, liquid bonding potential, Nernst slope, and proton activity coefficient, respectively.

In addition, $\gamma_{\mathrm{H}}{ }^{+}$and $E_{\mathrm{LJ}}$ remain in the fixed ionic strength. In this case, eq 1 can be rewritten as:

$E=E^{\prime} \mathrm{a}-k \mathrm{p}\left[\mathrm{H}^{+}\right]$

Where, $E_{\mathrm{a}}^{\prime}$ is $E_{\text {cell }}^{\circ}+k \log \gamma_{\mathrm{H}^{+}}+E_{\mathrm{LJ}}$.

Consequently, the values of $K$ and $E_{\text {a }}^{\prime}$ were calculated in calibration step using $E$ linear regression on $\left[\mathrm{H}^{+}\right]$.Results of calibration step are shown in Table 1.

Table 1. Calibration parameters of GLY-ASP in aqueous solution at temperatures $298.15 \mathrm{~K}$ to $318.15 \mathrm{~K}$ and $\mathrm{NaCl} 0.1 \mathrm{M}$.

\begin{tabular}{|c|c|c|}
\hline $\boldsymbol{T}(\boldsymbol{K})$ & $\boldsymbol{E}_{\boldsymbol{a}}^{\prime}(\boldsymbol{m} \boldsymbol{V})$ & $\boldsymbol{K}(\boldsymbol{m} \boldsymbol{V})$ \\
\hline 298.15 & 410.45 & 59.13 \\
\hline 303.15 & 416.76 & 59.17 \\
\hline 308.15 & 421.32 & 59.46 \\
\hline 313.15 & 426.28 & 59.24 \\
\hline 318.15 & 431.65 & 59.51 \\
\hline
\end{tabular}

Calibration parameters were used to determine concentration of hydrogen ions during titration in the second step for determining protonation constant.

Depending on $\mathrm{pH}$ of the solution, the GLY-ASP can exist in four different microforms which are $\left(\mathrm{H}_{3} \mathrm{~L}^{+}\right),\left(\mathrm{H}_{2} \mathrm{~L}\right)$, $\left(\mathrm{HL}^{-}\right)$, and $\left(\mathrm{L}^{2-}\right)$ species. These constants are expressed by eqs 6 to 8 :

$K_{1}=\frac{\left[H_{3} L^{+}\right]}{\left[H_{2} L\right]\left[\mathrm{H}^{+}\right]}$

$K_{2}=\frac{\left[H_{2} L\right]}{\left[H L^{-}\right]\left[\mathrm{H}^{+}\right]}$

$K_{3}=\frac{\left[H L^{-}\right]}{\left[\mathrm{L}^{2-}\right]\left[\mathrm{H}^{+}\right]}$

Based on Bjerrum's method, the fraction of protons bound to a ligand, $\bar{n}$, is given by eq $6[28]$ :

$\bar{n}_{\text {cal }}=\frac{\mathrm{C}_{\mathrm{H}}-\left[\mathrm{H}^{+}\right]}{\mathrm{C}_{\mathrm{L}}}$ 
where $\mathrm{C}_{\mathrm{H}}$ and $\mathrm{C}_{\mathrm{L}}$ are the total concentrations of protons and the GLY-ASP, respectively. Substituting, $\mathrm{C}_{\mathrm{L}}=\left[\mathrm{H}_{2} \mathrm{~L}^{+}\right]+\left[\mathrm{H}_{2} \mathrm{~L}\right]+\left[\mathrm{HL}^{-}\right]+\left[\mathrm{L}^{2-}\right]$ and $\mathrm{C}_{\mathrm{H}}=\left[\mathrm{H}^{+}\right]+$ $\left[\mathrm{HL}^{-}\right]+2\left[\mathrm{H}_{2} \mathrm{~L}\right]+3\left[\mathrm{H}_{3} \mathrm{~L}^{+}\right]$

Therefore, eq 6 can be rewritten as the eq 7 .

$\bar{n}_{c a l}=\frac{\left[\mathrm{H}_{3} \mathrm{~L}^{+}\right]+2\left[\mathrm{H}_{2} \mathrm{~L}\right]+3\left[\mathrm{HL}^{-}\right]}{\left[\mathrm{H}_{3} \mathrm{~L}^{+}\right]+\left[\mathrm{H}_{2} \mathrm{~L}\right]+\left[\mathrm{HL}^{-}\right]+\left[\mathrm{L}^{2}\right]}$

We can reach eq 8 using comparison eqs 3-5 and 7:

$\bar{n}_{c a l}=\frac{K_{1}\left[\mathrm{H}^{+}\right]+2 K_{1} K_{2}\left[\mathrm{H}^{+}\right]^{2}+3 K_{1} K_{2} K_{3}\left[\mathrm{H}^{+}\right]^{3}}{K_{1}\left[\mathrm{H}^{+}\right]+K_{1} K_{2}\left[\mathrm{H}^{+}\right]^{2}+K_{1} K_{2} K_{3}\left[\mathrm{H}^{+}\right]^{3}+1}$

Where, $\mathrm{K}_{1}$ and $\mathrm{K}_{2}$ represent the protonation constants of tow carboxylic acid groups and $\mathrm{K}_{3}$ represents the protonation constant of the amino groups of the GLY-ASP. On the other hand, electrical neutrality demands that the concentration of the cations should equal the concentration of the anions at all times during a titration, and hence:

$\bar{n}_{\text {exp }}=\frac{\mathrm{C}_{\mathrm{L}}+\left[\mathrm{Cl}^{-}\right]-\left[\mathrm{Na}^{+}\right]-\left[\mathrm{H}^{+}\right]+\left[\mathrm{OH}^{-}\right]}{\mathrm{C}_{\mathrm{L}}}$

In eq $9,\left[H^{+}\right]=10^{\left(E_{\text {cell }}-E^{\prime} \mathrm{a}\right) / \mathrm{k}}$ and $\left[\mathrm{OH}^{-}\right]$was determined as $\mathrm{K}_{\text {ap }} /\left[\mathrm{H}^{+}\right]$by knowing water auto-proteolysis constant, $K_{\text {ap }}$, from available literature $[29,30]$. Finally, using a suitable computer program (Microsoft Excel Solver) [31,32] the data from eqs 8 and 9 were fitted to estimate the protonation constants of GLYASP in the aqueous solution at different temperatures. We used the GaussNewton nonlinear least-squares method in the computer program to refine the $\bar{n}$ values by minimizing the sum of error squares:

$U=\sum\left(\bar{n}_{\text {exp }}-\bar{n}_{c a l)}{ }^{2}\right.$

Where, $\bar{n}_{\text {exp }}$ is an experimental $\bar{n}$ value and $\bar{n}_{\text {cal }}$ is the calculated one.

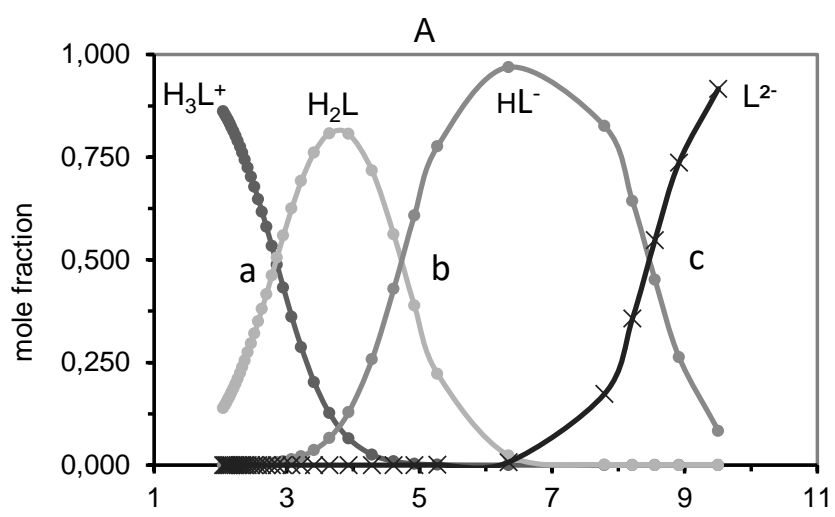

$\mathrm{pH}$

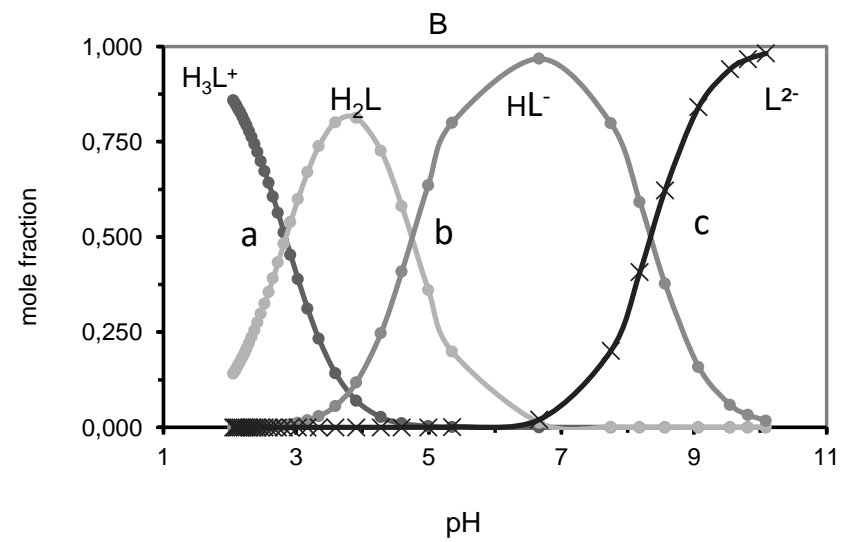

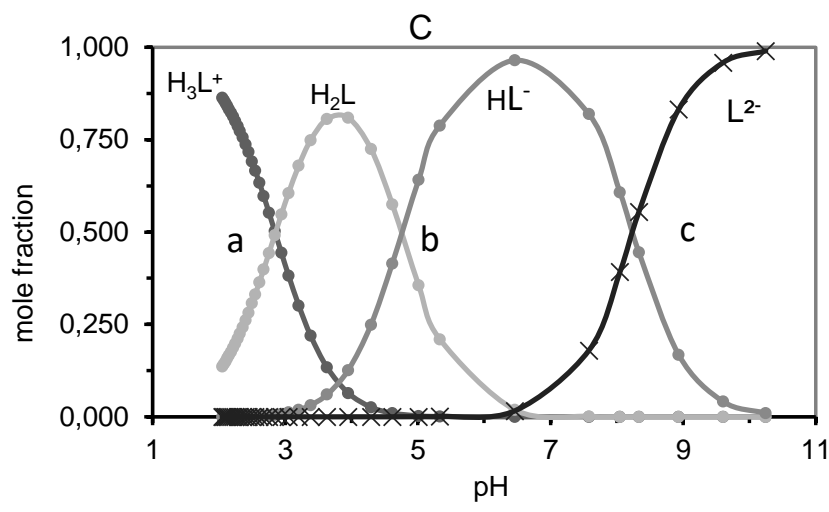
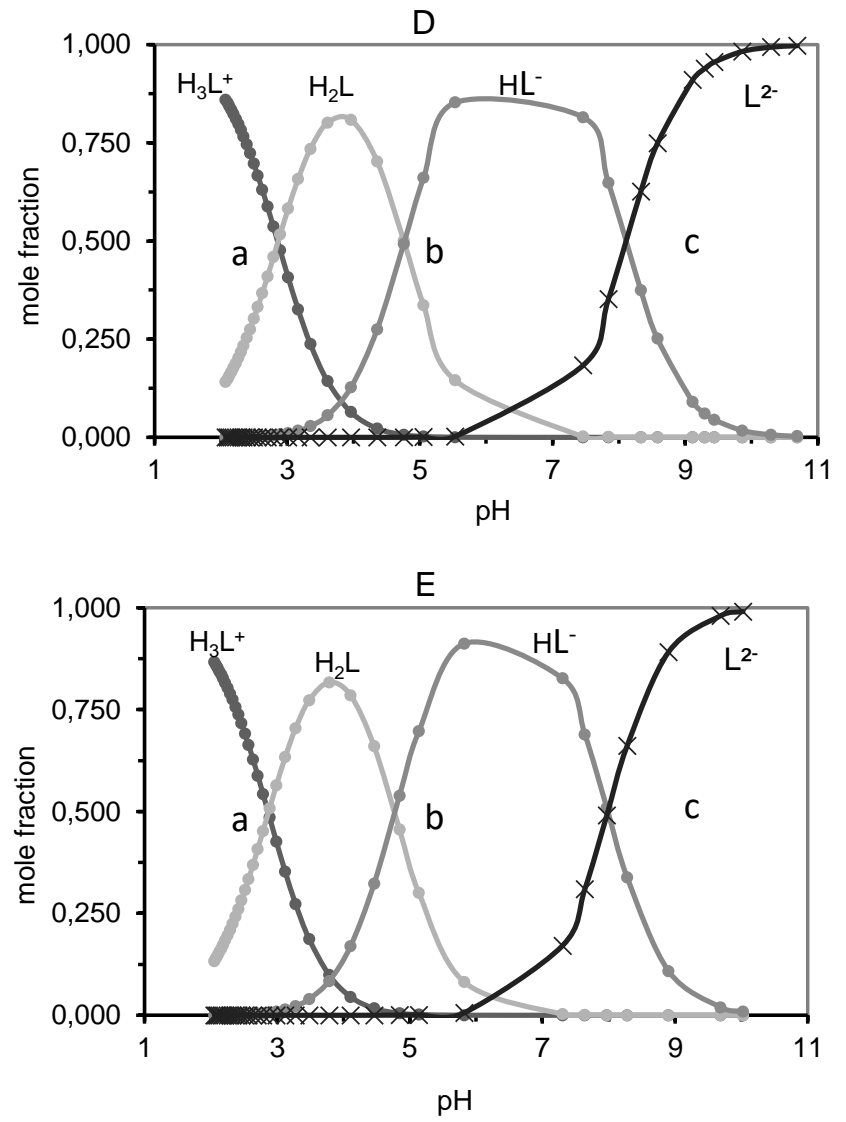

Figure3. Mole fraction diagrams obtained from titration in aqueous solution and ionic strength of $0.1 \mathrm{M}$ and temperatures (A) $\mathrm{T}=298.15 \mathrm{~K}$; (B) $303.15 \mathrm{~K}$; (C) $308.15 \mathrm{~K}$; (D) $313.15 \mathrm{~K}$; (E) $318.15 \mathrm{~K}$.

Figure 3 shows the mole fraction diagrams versus $\mathrm{pH}$ of solution for various species in the aqueous solution of GLY-ASP at different temperatures. This figure helps us find out the values of $\mathrm{pK}_{\mathrm{a}}, \mathrm{s}\left(\mathrm{pK}_{\mathrm{a} 1}, \mathrm{pK}_{\mathrm{a} 2}\right.$, and $\left.\mathrm{pK}_{\mathrm{a} 3}\right)$ for GLY-ASP in water at various temperatures. a, b, and c are the isoelectric points in Figure 3. In these points, the concentrations of the acid and the base are equal together. For an acid (HA), the following eq shows the relationship between $\mathrm{pK}_{\mathrm{a}}$ and $\mathrm{pH}$ in the aqueous solutions:

$p K_{a}=p H+\log \frac{\left[A^{-}\right]}{[H A]}$

In eq $11,\left[\mathrm{~A}^{-}\right]$and $[\mathrm{HA}]$ are the concentrations of acid $\mathrm{HA}$ and base $\mathrm{A}^{-}$. At isoelectric points $(\mathrm{a}, \mathrm{b}$, and $\mathrm{c}),\left[\mathrm{A}^{-}\right]=[\mathrm{HA}]$ and $\mathrm{pH}=\mathrm{pK}_{\mathrm{a}}$.

The experimentally determined $\mathrm{pK}_{\mathrm{a}}, \mathrm{s}$ of GLY-ASP, in aqueous solution, at various temperatures are listed in Table 2 . It can be seen in this table that the experimental $\mathrm{pKa}_{1}$ and $\mathrm{pKa}_{2}$ increase with temperature growth during the deprotonation process of GLY-ASP while the experimental and $\mathrm{pKa}_{3}$ decreases by temperature increasing. 
Table 2. Experimental and calculated protonation constants of GLY-ASP in aqueous solution at temperatures $298.15 \mathrm{~K}$ to $318.15 \mathrm{~K}$, in $\mathrm{NaCl} 0.1 \mathrm{M}$.

\begin{tabular}{|c|c|c|c|c|c|c|c|}
\hline Specie & $\boldsymbol{T}(\mathbf{K})$ & $\begin{array}{c}p \mathbf{K}_{a 1} \\
\text { (Exp) }\end{array}$ & $\begin{array}{c}p \mathbf{K}_{a 1} \\
\text { (Calcu) }\end{array}$ & $\begin{array}{c}p \mathbf{K}_{a 2} \\
\text { (Exp) }\end{array}$ & $\begin{array}{c}p \mathbf{K}_{a 2} \\
\text { (Calcu) }\end{array}$ & $\begin{array}{c}p \mathbf{K}_{a 3} \\
\text { (Exp) }\end{array}$ & $8.4 \mathbf{K}_{a 3}$ \\
(Calcu)
\end{tabular}

a: Ref. [32]

b: This work

Table 3. Thecalculated total free energy using Thomasi's method at the B3LYP/6-31+G(d) level of theory for cation, neutral, and anion species of GLY-ASP at $298.15 \mathrm{~K}$

\begin{tabular}{|c|c|c|c|c|c|}
\hline \multirow{2}{*}{ Specie } & $\mathrm{G}_{\text {sol }}^{\circ}$ & $\mathrm{G}_{\text {sol/molecule }}^{\circ}$ & \multirow{2}{*}{ Specie } & $\mathrm{G}_{\text {sol }}^{\circ}$ & $\mathrm{G}_{\text {sol/molecule }}^{\circ}$ \\
\hline & Hartree & $\mathrm{Kj} \cdot \mathrm{mol}^{-1}$ & & Hartree & $\mathrm{Kj} \cdot \mathrm{mol}^{-1}$ \\
\hline $\mathrm{H}_{3} \mathrm{~L}^{+}$ & -720.834 .828 & -1.892 .551 .659 & $\mathrm{HL}^{-}$ & -719.920 .077 & -1.890 .149 .981 \\
\hline $\mathrm{H}_{3} \mathrm{~L}^{+}\left(\mathrm{H}_{2} \mathrm{O}\right)$ & -797.277 .515 & -1.046 .625 .957 & $\mathrm{HL}^{-}\left(\mathrm{H}_{2} \mathrm{O}\right)$ & -796.358 .213 & -1.045 .419 .144 \\
\hline $\mathrm{H}_{3} \mathrm{~L}^{+}\left(\mathrm{H}_{2} \mathrm{O}\right)_{2}$ & -873.724 .961 & -7.646 .548 .883 & $\mathrm{HL}^{-}\left(\mathrm{H}_{2} \mathrm{O}\right)_{2}$ & -872.806 .288 & -7.638 .508 .964 \\
\hline $\mathrm{H}_{3} \mathrm{~L}^{+}\left(\mathrm{H}_{2} \mathrm{O}\right)_{3}$ & -950.167 .261 & -6.236 .659 .761 & $\mathrm{HL}^{-}\left(\mathrm{H}_{2} \mathrm{O}\right)_{3}$ & -949.248 .804 & -6.230 .631 .239 \\
\hline $\mathrm{H}_{3} \mathrm{~L}^{+}\left(\mathrm{H}_{2} \mathrm{O}\right)_{4}$ & -102.660 .636 & -5.390 .709 .479 & $\mathrm{HL}^{-}\left(\mathrm{H}_{2} \mathrm{O}\right)_{4}$ & -102.570 .158 & -538.595 .848 \\
\hline $\mathrm{H}_{2} \mathrm{~L}$ & -720.367 .585 & -1.891 .324 .913 & $\mathrm{~L}^{2-}$ & -7.194 .688 & -1.888 .965 .153 \\
\hline $\mathrm{H}_{2} \mathrm{~L}\left(\mathrm{H}_{2} \mathrm{O}\right)$ & -796.815 .803 & -1.046 .019 .845 & $\mathrm{~L}^{2-}\left(\mathrm{H}_{2} \mathrm{O}\right)$ & -795.910 .757 & -1.044 .831 .746 \\
\hline $\mathrm{H}_{2} \mathrm{~L}\left(\mathrm{H}_{2} \mathrm{O}\right)_{2}$ & -873.267 .474 & -764.254 .511 & $\mathrm{~L}^{2-}\left(\mathrm{H}_{2} \mathrm{O}\right)_{2}$ & -872.352 .787 & -7.634 .540 .075 \\
\hline $\mathrm{H}_{2} \mathrm{~L}\left(\mathrm{H}_{2} \mathrm{O}\right)_{3}$ & -949.694 .754 & -6.233 .558 .343 & $\mathrm{~L}^{2-}\left(\mathrm{H}_{2} \mathrm{O}\right)_{3}$ & -948.800 .422 & -6.227 .688 .172 \\
\hline $\mathrm{H}_{2} \mathrm{~L}\left(\mathrm{H}_{2} \mathrm{O}\right)_{4}$ & -1.026 .156 .069 & -5.388 .345 .001 & $\mathrm{~L}^{2-}\left(\mathrm{H}_{2} \mathrm{O}\right)_{4}$ & -1.025 .243 .322 & -5.383 .552 .167 \\
\hline $\mathrm{H}_{2} \mathrm{O}$ & -7.643 .735 & -2.006 .862 .432 & $\mathrm{OH}^{-}$ & -7.594 .893 & -1.994 .038 .966 \\
\hline $2 \mathrm{H}_{2} \mathrm{O}$ & -1.528 .798 & -4.013 .858 .764 & $\mathrm{OH}^{-}\left(\mathrm{H}_{2} \mathrm{O}\right)$ & -15.239 .712 & -2.000 .593 .001 \\
\hline $3 \mathrm{H}_{2} \mathrm{O}$ & -229.321 .345 & -6.020 .831 .335 & $\mathrm{OH}^{-}\left(\mathrm{H}_{2} \mathrm{O}\right)_{2}$ & -22.884 .536 & -2.002 .778 .117 \\
\hline $4 \mathrm{H}_{2} \mathrm{O}$ & -30.572 .828 & -8.026 .895 .221 & $\mathrm{OH}^{-}\left(\mathrm{H}_{2} \mathrm{O}\right)_{3}$ & -30.522 .555 & -2.003 .424 .012 \\
\hline $5 \mathrm{H}_{2} \mathrm{O}$ & -38.218 .675 & -1.003 .431 .216 & - & - & - \\
\hline
\end{tabular}

\subsection{Theoretical results and discussion}

The $\mathrm{pK}_{\mathrm{a}}$ quantity is a molecular tendency to lose a proton $\left(\mathrm{H}^{+}\right)$. GLY-ASP loses proton from two carboxyl groups, in the first and second steps of the ionization reaction, and loses proton from the ammonium group in the third step of the ionization reaction. The microscopic ionization constants $\mathrm{k}_{1}, \mathrm{k}_{2}$, and $\mathrm{k}_{3}$ can be applied, wherein $k_{1}$ and $k_{2}$ involve two carboxyl groups and $k_{3}$ involves the ammonium group [33].

$k_{1}=\frac{\left[\mathrm{H}^{+}\right]\left[\mathrm{NH}_{3}{ }^{+} \mathrm{CH}_{2} \mathrm{CONHCH}(\mathrm{COOH}) \mathrm{CH}_{2} \mathrm{COO}^{-}\right]}{\left[\mathrm{NH}_{3}{ }^{+} \mathrm{CH}_{2} \mathrm{CONHCH}(\mathrm{COOH}) \mathrm{CH}_{2} \mathrm{COOH}\right]}$

$k_{2}=\frac{\left[\mathrm{H}^{+}\right]\left[\mathrm{NH}_{3}{ }^{+} \mathrm{CH}_{2} \mathrm{CONHCH}\left(\mathrm{COO}^{-}\right) \mathrm{CH}_{2} \mathrm{COO}^{-}\right]}{\left[\mathrm{NH}_{3}{ }^{+} \mathrm{CH}_{2} \mathrm{CONHCH}(\mathrm{COOH}) \mathrm{CH}_{2} \mathrm{COO}^{-}\right]}$

$k_{3}=\frac{\left[\mathrm{H}^{+}\right]\left[\mathrm{NH}_{2} \mathrm{CH}_{2} \mathrm{CONHCH}\left(\mathrm{COO}^{-}\right) \mathrm{CH}_{2} \mathrm{COO}^{-}\right]}{\left[\mathrm{NH}_{3}{ }^{+} \mathrm{CH}_{2} \mathrm{CONHCH}\left(\mathrm{COO}^{-}\right) \mathrm{CH}_{2} \mathrm{COO}^{-}\right]}$

The total free energies for cation, anion, and neutral species of GLY-ASP, in water, were calculated using B3LYP/6-31+G(d) theory by Thomasi's method. Table 3 shows the values of the total free energy $\left(\mathrm{G}_{\text {sol }}^{\circ}\right)$ for selected species of GLY-ASP at $298.15 \mathrm{~K}$.

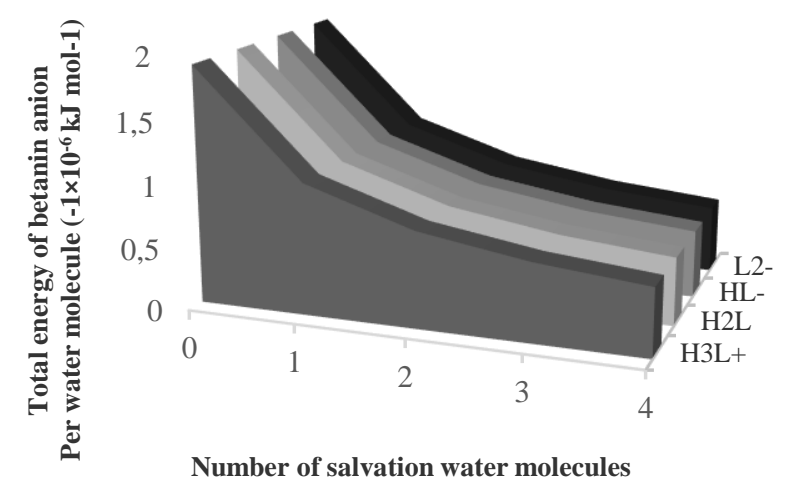

Number of salvation water molecules

口H3L+ $\square \mathrm{H} 2 \mathrm{~L}$ 口HL- 田2-

Figure 4. Plot of the total free energy $\left(\mathrm{kJ} \mathrm{mol}^{-1}\right)$ of solvated species of GLYASP per water molecule against the total number of solvation water molecules at $298.15 \mathrm{~K}$. 
It can be seen in Table 3 and Figure 4 that the values of total free energy $\left(\mathrm{Kj}_{\mathrm{mol}}{ }^{-1}\right)$ increase for all species of GLY-ASP as the number of water molecules involved in solvation increases. This subject shows that the solvation process for all species of GLY-ASP has endothermic nature.

\subsubsection{The first dissociation constant of the GLY-ASP}

In aqueous solution, the cation specie of GLY-ASP can involve in the below reaction:

$\mathrm{H}_{3} \mathrm{~L}^{+}\left(\mathrm{H}_{2} \mathrm{O}\right)_{4}+\mathrm{OH}^{-}\left(\mathrm{H}_{2} \mathrm{O}\right)_{3} \rightleftarrows \mathrm{H}_{2} \mathrm{~L}\left(\mathrm{H}_{2} \mathrm{O}\right)_{3}+5 \mathrm{H}_{2} \mathrm{O} \quad \mathrm{K}_{\mathrm{c} 1}$
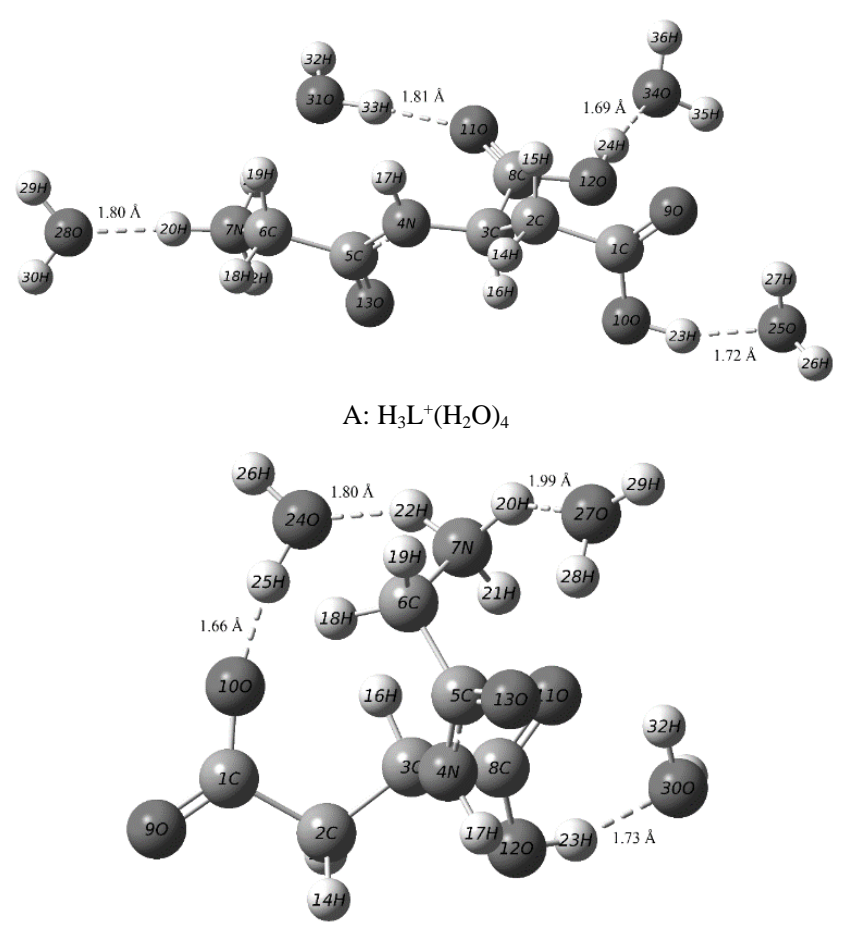

B: $\mathrm{H}_{2} \mathrm{~L}\left(\mathrm{H}_{2} \mathrm{O}\right)_{3}$

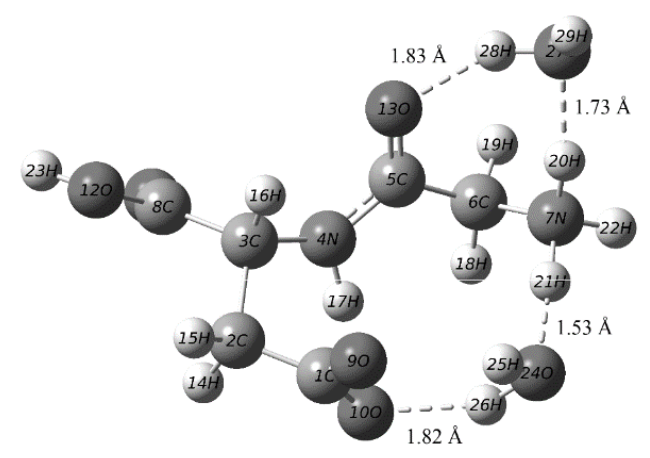

C: $\mathrm{H}_{2} \mathrm{~L}\left(\mathrm{H}_{2} \mathrm{O}\right)_{2}$

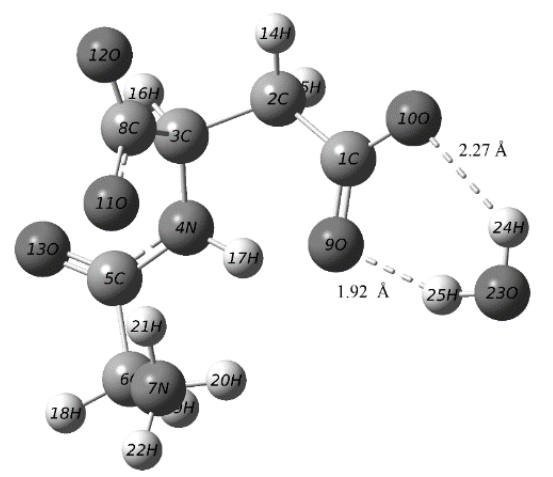

D: $\mathrm{HL}^{-}\left(\mathrm{H}_{2} \mathrm{O}\right)$

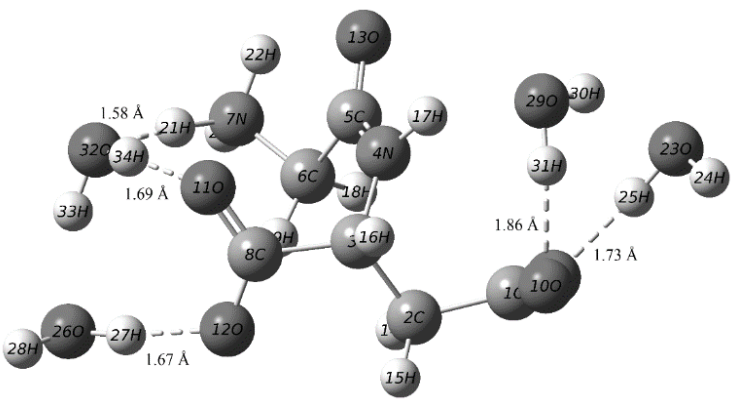

E: $\mathrm{HL}^{-}\left(\mathrm{H}_{2} \mathrm{O}\right)_{4}$

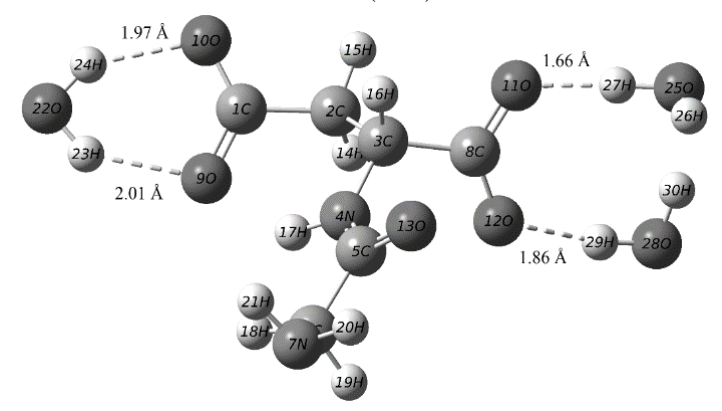

F: $\mathrm{L}^{2-}\left(\mathrm{H}_{2} \mathrm{O}\right)_{3}$

Figure 5. Calculated structure for GLY-ASP solvated with water molecules at the B3LYP/6-31+G(d) level of theory using Thomasi's method in water at $298.15 \mathrm{~K}$.

In which $\mathrm{H}_{3} \mathrm{~L}^{+}\left(\mathrm{H}_{2} \mathrm{O}\right)_{4}$ (Figure5-A) and $\mathrm{H}_{2} \mathrm{~L}\left(\mathrm{H}_{2} \mathrm{O}\right)_{3}$ (Figure5-B) show the cation species of GLY-ASP solvated with four water molecules and neutral species of GLY-ASP solvated with three water molecules, respectively. $\mathrm{K}_{\mathrm{c} 1}$ indicates the equilibrium constant of eq 15 . This constant was theoretically calculated.

In aqueous solutions, the autoproteolysis process can happen for two, three, four, and five water molecules. In this study, the autoproteolysis process happened for five water molecules according to the below eq:

$$
\begin{aligned}
& 5 \mathrm{H}_{2} \mathrm{O} \rightleftarrows \mathrm{H}_{3} \mathrm{O}^{+}+\mathrm{OH}^{-}\left(\mathrm{H}_{2} \mathrm{O}\right)_{3} \quad \mathrm{~K}_{\mathrm{N} 3} \\
& \mathrm{~K}_{\mathrm{w}}=\mathrm{K}_{\mathrm{N} 3}\left[\mathrm{H}_{2} \mathrm{O}\right]^{3} \\
& \mathrm{~K}_{\mathrm{N} 3}=\frac{\mathrm{K}_{\mathrm{W}}}{\left[\mathrm{H}_{2} \mathrm{O}\right]^{3}}=6.4149 \times 10^{-20}
\end{aligned}
$$

In eq $18, \mathrm{~K}_{\mathrm{W}}=1.0081 \times 10^{-14}$ at $\mathrm{T}=298.15 \mathrm{~K}$. This shows that only a few water molecules were ionized to $\mathrm{H}^{+}$and $\mathrm{OH}^{-}$ions [34].

eq 19 is obtained by combining eqs 15 and 16 :

$$
\mathrm{H}_{3} \mathrm{~L}^{+}\left(\mathrm{H}_{2} \mathrm{O}\right)_{4} \rightleftarrows \mathrm{H}_{2} \mathrm{~L}\left(\mathrm{H}_{2} \mathrm{O}\right)_{3}+\mathrm{H}_{3} \mathrm{O}^{+} \quad \mathrm{K}_{\mathrm{a} 1}
$$

It is clear that the value of constant $\mathrm{K}_{\mathrm{al}}$ can be calculated according to the following eq:

$$
\mathrm{K}_{\mathrm{a} 1}=\mathrm{K}_{\mathrm{N} 3} \times \mathrm{K}_{\mathrm{c} 1}
$$

The reaction of eq 19 shows the first ionization process of GLY-ASP. $K_{a 1}$ is applied to calculate the first acid dissociation constant $\left(\mathrm{pK}_{\mathrm{a} 1}\right)$ of GLY-ASP. For GLY-ASP, the calculated values of $\mathrm{pK}_{\mathrm{a} 1}$, at various temperatures, are listed in Table 2. Table 2 shows that there is a good agreement between theoretically calculated and experimentally determined values of $\mathrm{pK}_{\mathrm{a} 1}$ for GLY-ASP at various temperatures.

Table 4 summarizes the optimized values of molecular properties for various species of GLY-ASP, in water, obtained at the B3LYP/6-31+G(d) level of theory with Tomasi's method at $298.15 \mathrm{~K}$. As it can be seen in this table, the negative atomic charge of $\mathrm{O}_{10}$ atom $\left(\mathrm{q}_{\mathrm{O} 10}\right)$, in $\mathrm{H}_{2} \mathrm{~L}\left(\mathrm{H}_{2} \mathrm{O}\right)_{3}$, increases compared to that of in $\mathrm{H}_{3} \mathrm{~L}^{+}\left(\mathrm{H}_{2} \mathrm{O}\right)_{4}$ specie. It shows that the density of negative atomic charge increases in $\mathrm{O}_{10}$ atom during the first ionization process of GLY-ASP. This indicates that $\mathrm{H}^{+}$is separated from $\mathrm{O}_{10}$ atom in the first ionization process of GLY-ASP, $\left(\mathrm{pK}_{\mathrm{a} 1}\right)$. 
Table 4. The calculated structural magnitudes using Thomasi's method at the B3LYP/6-31+G(d) level of theory for the cation, neutral, and anion of GLY-ASP at $298.15 \mathrm{~K}$

\begin{tabular}{|c|c|c|c|c|c|c|}
\hline \multirow{2}{*}{$\begin{array}{l}\text { Calculated } \\
\text { magnitudes }\end{array}$} & \multicolumn{6}{|c|}{ specie } \\
\hline & $\mathbf{H}_{3} \mathbf{L}^{+}\left(\mathbf{H}_{2} \mathbf{O}\right)_{4}$ & $\mathbf{H}_{2} \mathbf{L}\left(\mathbf{H}_{2} \mathbf{O}\right)_{2}$ & $\mathbf{H}_{2} \mathbf{L}\left(\mathbf{H}_{2} \mathbf{O}\right)_{3}$ & $\mathbf{H L}^{-}\left(\mathbf{H}_{2} \mathbf{O}\right)$ & $\mathrm{HL}^{-}\left(\mathrm{H}_{2} \mathrm{O}\right)_{4}$ & $\mathbf{L}^{2-}\left(\mathbf{H}_{2} \mathbf{O}\right)_{3}$ \\
\hline & \multicolumn{6}{|c|}{ q: Total atomic charge (Muliken) (au) } \\
\hline $\mathrm{q}_{\mathrm{C} 1}$ & 0.651756 & 0.566695 & 0.652006 & 0.665395 & 0.335896 & 0.556615 \\
\hline $\mathrm{q}_{\mathrm{C} 2}$ & -0.469916 & -0.572008 & -0.926321 & -0.658725 & -0.196794 & -0.441520 \\
\hline $\mathrm{q}_{\mathrm{C} 3}$ & -0.857076 & -0.537964 & -0.059799 & -0.372012 & -0.154239 & -0.457014 \\
\hline $\mathrm{q}_{\mathrm{N} 4}$ & -0.287580 & -0.412129 & -0.458344 & -0.611813 & -0.470768 & -0.416254 \\
\hline $\mathrm{q}_{\mathrm{C} 5}$ & 0.443535 & 0.617521 & 0.569309 & 0.769104 & 0.279241 & 0.682373 \\
\hline $\mathrm{q}_{\mathrm{C} 6}$ & -0.199821 & -0.313098 & -0.200987 & -0.404532 & 0.026503 & -0.482376 \\
\hline $\mathrm{q}_{\mathrm{N} 7}$ & -1.047778 & -1.158053 & -1.174469 & -1.036543 & -1.133027 & -0.944343 \\
\hline $\mathrm{q}_{\mathrm{C} 8}$ & 0.913028 & 0.862267 & 0.642153 & 0.674438 & 0.195161 & 0.617228 \\
\hline qo9 & -0.593115 & -0.681269 & -0.691673 & -0.798784 & -0.684806 & -0.747558 \\
\hline qo10 & -0.665393 & -0.718271 & -0.786261 & -0.720063 & -0.687635 & -0.747719 \\
\hline qo11 & -0.609144 & -0.523335 & -0.559590 & -0.552001 & -0.687759 & -0.726398 \\
\hline qo12 & -0.670961 & -0.616937 & -0.639145 & -0.625117 & -0.644641 & -0.723690 \\
\hline \multirow[t]{2}{*}{ qo13 } & -0.609057 & -0.671771 & -0.630512 & -0.647621 & -0.639551 & -0.687509 \\
\hline & \multicolumn{6}{|c|}{ d: Distance between the indicated atoms $(\AA)$} \\
\hline $\mathrm{d}_{\mathrm{C} 1-\mathrm{C} 2}$ & 1.522524 & 1.54387 & 1.57639 & 1.56141 & 1.54276 & 1.54953 \\
\hline $\mathrm{d}_{\mathrm{Cl}-\mathrm{O} 9}$ & 1.219051 & 1.25105 & 1.23201 & 1.28659 & 1.26692 & 1.27954 \\
\hline $\mathrm{d}_{\mathrm{C} 2-\mathrm{H} 14}$ & 1.097349 & 1.09517 & 1.09396 & 1.09236 & 1.09405 & 1.09909 \\
\hline $\mathrm{d}_{\mathrm{C} 3-\mathrm{N} 4}$ & 1.458984 & 1.46046 & 1.47128 & 1.45180 & 1.47906 & 1.46059 \\
\hline \multirow[t]{2}{*}{$\mathrm{d}_{\mathrm{N} 4-\mathrm{H} 17}$} & 1.013753 & 1.02083 & 1.01673 & 1.03515 & 1.03124 & 1.02568 \\
\hline & \multicolumn{6}{|c|}{ A: Angles between the indicated atoms $\left({ }^{\circ}\right)$} \\
\hline $\mathrm{A}_{\mathrm{C} 2-\mathrm{C} 1-\mathrm{O} 9}$ & 122.82867 & 118.32466 & 116.37500 & 117.59091 & 116.87168 & 116.03662 \\
\hline $\mathrm{A}_{\mathrm{O} 9-\mathrm{Cl}-\mathrm{O} 10}$ & 124.75031 & 126.56537 & 128.01527 & 126.22749 & 126.54145 & 125.82270 \\
\hline $\mathrm{A}_{\mathrm{C} 1-\mathrm{C} 2-\mathrm{C} 3}$ & 114.63935 & 107.41386 & 110.19841 & 117.94932 & 109.44702 & 115.89851 \\
\hline $\mathrm{A}_{\mathrm{C} 1-\mathrm{C} 2-\mathrm{H} 14}$ & 106.85975 & 109.72167 & 109.43062 & 108.30701 & 110.07974 & 107.25619 \\
\hline $\mathrm{A}_{\mathrm{H} 14-\mathrm{C} 2-\mathrm{H} 15}$ & 108.04726 & 109.6044 & 106.85058 & 107.06760 & 107.88843 & 108.33622 \\
\hline $\mathrm{A}_{\mathrm{N} 4-\mathrm{C} 3-\mathrm{C} 8}$ & 109.87279 & 111.00077 & 106.76830 & 113.11783 & 110.12963 & 113.66091 \\
\hline $\mathrm{A}_{\mathrm{N} 4-\mathrm{C} 3-\mathrm{H} 16}$ & 107.70161 & 107.80059 & 107.15360 & 110.38409 & 104.04371 & 108.97040 \\
\hline $\mathrm{A}_{\mathrm{N} 4-\mathrm{C} 5-\mathrm{O} 13}$ & 124.89052 & 124.80483 & 123.00890 & 125.45978 & 126.02343 & 125.87278 \\
\hline \multirow[t]{2}{*}{$\mathrm{A}_{\mathrm{O} 11-\mathrm{C} 8 \mathrm{-O} 12}$} & 124.65657 & 123.25751 & 123.50981 & 120.49945 & 126.49487 & 127.57625 \\
\hline & & \multicolumn{5}{|c|}{ D: dihedral angle between the indicated atoms $\left({ }^{\circ}\right)$} \\
\hline $\mathrm{D}_{\mathrm{O} 9 \mathrm{C} 1 \mathrm{C} 2 \mathrm{H} 14}$ & -105.21793 & -153.2557 & -39.41902 & 150.62301 & 11.11925 & 56.79998 \\
\hline $\mathrm{D}_{\mathrm{C} 1 \mathrm{C} 2 \mathrm{C} 3 \mathrm{~N} 4_{4}}$ & 164.83102 & 41.60976 & 89.76473 & -48.34314 & 49.42594 & 47.48304 \\
\hline $\mathrm{D}_{\mathrm{N} 4 \mathrm{C} 3011 \mathrm{C} 8}$ & -179.63306 & -166.47574 & 112.90153 & -166.82993 & 142.15863 & 37.33348 \\
\hline $\mathrm{D}_{\mathrm{H} 17 \mathrm{~N} 4 \mathrm{O} 13 \mathrm{C} 5}$ & 162.879 & -165.7033 & -179.42055 & -3.82956 & 168.25217 & 24.18107 \\
\hline $\mathrm{D}_{\mathrm{O} 13 \mathrm{C} 5 \mathrm{C} 6 \mathrm{~N} 7}$ & -35.49073 & 62.81359 & 100.89486 & -124.12082 & -38.33232 & 30.77337 \\
\hline $\mathrm{D}_{\mathrm{H} 16 \mathrm{C} 3 \mathrm{~N} 4 \mathrm{H} 17}$ & 163.50637 & 140.83215 & -178.50844 & 153.47773 & 20.44457 & 114.63236 \\
\hline $\mathrm{D}_{\mathrm{C} 3 \mathrm{~N} 4 \mathrm{H} 17 \mathrm{C} 5}$ & 158.98503 & 151.43811 & 165.76673 & 154.31781 & 179.92230 & -164.01299 \\
\hline
\end{tabular}

\subsubsection{The second ionization constant of GLY-ASP}

GLY-ASP can lose the second hydrogen cation when involved in the following reaction:

$\mathrm{H}_{2} \mathrm{~L}\left(\mathrm{H}_{2} \mathrm{O}\right)_{2}+\mathrm{OH}^{-}\left(\mathrm{H}_{2} \mathrm{O}\right)_{3} \rightleftarrows \mathrm{HL}^{-}\left(\mathrm{H}_{2} \mathrm{O}\right)+5 \mathrm{H}_{2} \mathrm{O}$

In which $\mathrm{H}_{2} \mathrm{~L}\left(\mathrm{H}_{2} \mathrm{O}\right)_{2}$ (Figure5-C) and $\mathrm{HL}^{-}\left(\mathrm{H}_{2} \mathrm{O}\right)$ (Figure5-D) show the neutral species of GLY-ASP solvated with two water molecules and the anion species of GLY-ASP solvated with one water molecules, respectively. $\mathrm{K}_{\mathrm{c} 2}$ indicates the equilibrium constant of eq 21 . The value of this constant was theoretically calculated.
The autoproteolysis reaction of five water molecules occurs in the second ionization process of GLY-ASP.

eq 22 is obtained by combining eqs 21 and 16 :

$\mathrm{H}_{2} \mathrm{~L}\left(\mathrm{H}_{2} \mathrm{O}\right)_{2} \rightleftarrows \mathrm{HL}^{-}\left(\mathrm{H}_{2} \mathrm{O}\right)+\mathrm{H}_{3} \mathrm{O}^{+}$

$\mathrm{K}_{\mathrm{a} 2} \quad(22)$

It is obvious that the value of the constant $\mathrm{K}_{\mathrm{a} 2}$ can be calculated using $\mathrm{K}_{\mathrm{N} 3}$ and $\mathrm{K}_{\mathrm{C} 2}$ according to the eq below:

$\mathrm{K}_{\mathrm{a} 2}=\mathrm{K}_{\mathrm{N} 3} \times \mathrm{K}_{\mathrm{c} 2}$ 
The reaction of eq 22 shows the second ionization process of GLY-ASP. $\mathrm{K}_{\mathrm{a} 2}$ is applied to calculate the second acid dissociation constant of GLY-ASP. For GLY-ASP, the calculated values of $\mathrm{pK}_{\mathrm{a} 2}$, at various temperatures, are listed in Table 2. As it can be seen in Table 2, the theoretically calculated and experimentally determined values of $\mathrm{pK}_{\mathrm{a} 2}$ are very close together.

Table 4 shows that the negative value of atomic charge for the $\mathrm{O}_{12}$ atom ( $\mathrm{q}_{\mathrm{o} 22}$ ), in $\mathrm{HL}^{-}\left(\mathrm{H}_{2} \mathrm{O}\right)$, increases compared to that of in $\mathrm{H}_{2} \mathrm{~L}\left(\mathrm{H}_{2} \mathrm{O}\right)_{2}$. It shows that the density of negative charge increases in the $\mathrm{O}_{12}$ atom during the second ionization process of GLY-ASP. This subject indicates that $\mathrm{H}^{+}$is separated from the $\mathrm{O}_{12}$ atom during the second ionization process of GLY-ASP $\left(\mathrm{pK}_{\mathrm{a} 2}\right)$.

\subsubsection{The third ionization constant of GLY-ASP}

In aqueous solutions, anion specie of GLY-ASP can participate in the below reaction:

$\mathrm{HL}^{-}\left(\mathrm{H}_{2} \mathrm{O}\right)_{4}+\mathrm{OH}^{-}\left(\mathrm{H}_{2} \mathrm{O}\right)_{3} \rightleftarrows \mathrm{L}^{2-}\left(\mathrm{H}_{2} \mathrm{O}\right)_{3}+5 \mathrm{H}_{2} \mathrm{O}$

$\mathrm{K}_{\mathrm{c} 3}$

In which $\mathrm{HL}^{-}\left(\mathrm{H}_{2} \mathrm{O}\right)_{4}$ (Figure5-E) and $\mathrm{L}^{2-}\left(\mathrm{H}_{2} \mathrm{O}\right)_{3}$ (Figure5-F) show the anion species of GLY-ASP solvated with four and three water molecules, respectively. $\mathrm{Kc}_{3}$ indicates the equilibrium constant of eq 24 . The value of this constant was theoretically calculated.

The autoproteolysis reaction of five water molecules can happen during the third ionization process of GLY-ASP

eq 25 is obtained by combining eqs 24 and 16 :

$\mathrm{HL}^{-}\left(\mathrm{H}_{2} \mathrm{O}\right)_{4} \rightleftarrows \mathrm{L}^{2-}\left(\mathrm{H}_{2} \mathrm{O}\right)_{3}+\mathrm{H}_{3} \mathrm{O}^{+}$

$\mathrm{K}_{\mathrm{a} 3}$

It is obvious that the value of the constant $\mathrm{K}_{\mathrm{a} 3}$ can be calculated using $\mathrm{K}_{\mathrm{N} 3}$ and $\mathrm{K}_{\mathrm{c} 3}$ according to the below eq:

$\mathrm{K}_{\mathrm{a} 3}=\mathrm{K}_{\mathrm{N} 3} \times \mathrm{K}_{\mathrm{c} 3}$

The reaction of eq 25 shows the third ionization process of GLY-ASP. $\mathrm{K}_{\mathrm{a} 3}$ is applied to calculate the third acid dissociation constant of GLY-ASP. For GLYASP, the calculated values of $\mathrm{pK}_{\mathrm{a} 3}$, at various temperatures, are listed in Table 2. As it can be seen in Table 2, the theoretically calculated value of $\mathrm{pK}_{\mathrm{a} 3}$ is very close to experimentally determined one at various temperatures.

Table 4 shows that the absolute value atomic charge for $\mathrm{N}_{7}$ atom $\left(\mathrm{q}_{\mathrm{N} 7}\right)$, in $\mathrm{L}^{2-}$ $\left(\mathrm{H}_{2} \mathrm{O}\right)_{3}$, decreases compared to that of in $\mathrm{HL}^{-}\left(\mathrm{H}_{2} \mathrm{O}\right)_{4}$. It shows that the density of negative charge decreases in the $\mathrm{N}_{7}$ atom during the third ionization process of GLY-ASP. This subject indicates that $\mathrm{H}^{+}$is separated from the $\mathrm{N}_{7}$ atom during the third ionization process of GLY-ASP $\left(\mathrm{pK}_{\mathrm{a} 3}\right)$.

For involving species in the first, second, and third ionization process of GLYASP, the values of total free energy were calculated at various temperatures $(\mathrm{T}=$ $298.15 \mathrm{~K}, 303.15 \mathrm{~K}, 308.15 \mathrm{~K}, 313.15 \mathrm{~K}$, and $318.15 \mathrm{~K}$ ) using the B3LYP/6$31+\mathrm{G}(\mathrm{d})$ surface theory by Thomasi's method. The obtained data have been listed in Table 5.

For GLY-ASP, the values of $\mathrm{pK}_{\mathrm{a} 1}, \mathrm{pK}_{\mathrm{a} 2}$, and $\mathrm{pK}_{\mathrm{a} 3}$, at various temperatures, were calculated using data of Table 5. The obtained results $\left(\mathrm{pK}_{\mathrm{a} 1}, \mathrm{pK}_{\mathrm{a} 2}\right.$, and $\mathrm{pK}_{\mathrm{a} 3}$, at various temperatures) were listed in Table 2. According to Table 2, the $\mathrm{pK}_{\mathrm{a} 1}$ and $\mathrm{pK}_{\mathrm{a} 2}$ increase and also, the $\mathrm{pK}_{\mathrm{a} 3}$ decrease with temperature growth.

\section{STUDYING ON HYDROGEN BONDING}

In a solution, we can find out the power of the interaction between solute and solvent molecules by calculation of distance between them (in $\AA$ ). The shorter distance between molecules shows the stronger interaction between them. The water molecules which originated from the acid-base reaction and the hydration water molecule of GLY-ASP can contribute to intermolecular hydrogen bonding $\left(\mathrm{IHB}_{\mathrm{s}}\right)$. The power of hydrogen bond is based on their length, angle, and energy as strong, medium, and weak. In strong, medium, and weak hydrogen bonds the bond lengths are 1.2 to $2.2,1.5$ to 2.2 , and 2.2 to 3.2 Angstrom, respectively. Also, the bond angles in weak, moderate, and strong hydrogen bonds are $175^{\circ}$ to $180^{\circ}, 130^{\circ}$ to $180^{\circ}$, and $90^{\circ}$ to $150^{\circ}$, respectively $[35,36]$. The data of Tables 4 and Figure 5 show that all species of GLY-ASP generate moderate hydrogen bonding with water molecules. It must be noted that IHB data can be used to design and predict nano drugs. They can be conjugated to biomolecules and have a widespread application in medical science $[37,38]$.

\section{THERMODYNAMIC ANALYSIS}

The changes of Gibbs free energy $(\Delta \mathrm{G})$, enthalpy $(\Delta \mathrm{H})$, and entropy $(\Delta \mathrm{S})$ are important thermodynamic parameters. The $\Delta \mathrm{G}$ is the key parameter, because its value under a particular set of reactant concentrations dictates the direction of biomolecules equilibria in solutions. If its sign is negative, the binding reaction or conformational transition will proceed spontaneously to an extent governed by the magnitude of $\Delta \mathrm{G}$. If its sign is positive, the magnitude of $\Delta \mathrm{G}$ specifies the energy needed to drive the reaction to form product. The free energy is a balance between enthalpy and entropy [39-41].

Change of free energy in gas or solution phases can be calculated using the below eq:

$$
\Delta \mathrm{G}=-\mathrm{RT} \ln K_{a} \approx 2.303 \mathrm{RT} \mathrm{p} K_{a}
$$

In eq $30, \mathrm{R}$ is universal gas constant $\left(8.314 \mathrm{~K}^{-1} \mathrm{~J} \mathrm{~mol}^{-1}\right)$, $\mathrm{T}$ is the temperature $(\mathrm{K})$, and $\mathrm{K}_{\mathrm{a}}$ is the equilibrium constant process.

The values of $\Delta \mathrm{H}$ and $\Delta \mathrm{S}$ can be obtained using Van't Hoff eq (by plotting ln $\mathrm{K}_{\mathrm{a}}$ versus $\left.1 / \mathrm{T}\right)[42]$ :

$$
\mathrm{pK}_{\mathrm{a}}=\Delta \mathrm{H} / 2.303 \mathrm{RT}-\Delta \mathrm{S} / 2.303 \mathrm{R}
$$

The sign of $\Delta \mathrm{G}, \Delta \mathrm{H}$, and $\Delta \mathrm{S}$ can show the state of chemical reactions. Chemical reactions can be spontaneous at each temperature when $\Delta \mathrm{G}$ and $\Delta \mathrm{H}$ have negative and $\Delta \mathrm{S}$ has positive values $[43,44]$. The values of temperature can affect the state of chemical reactions when $\Delta \mathrm{H}$ and $\Delta \mathrm{S}$ have the same signs.

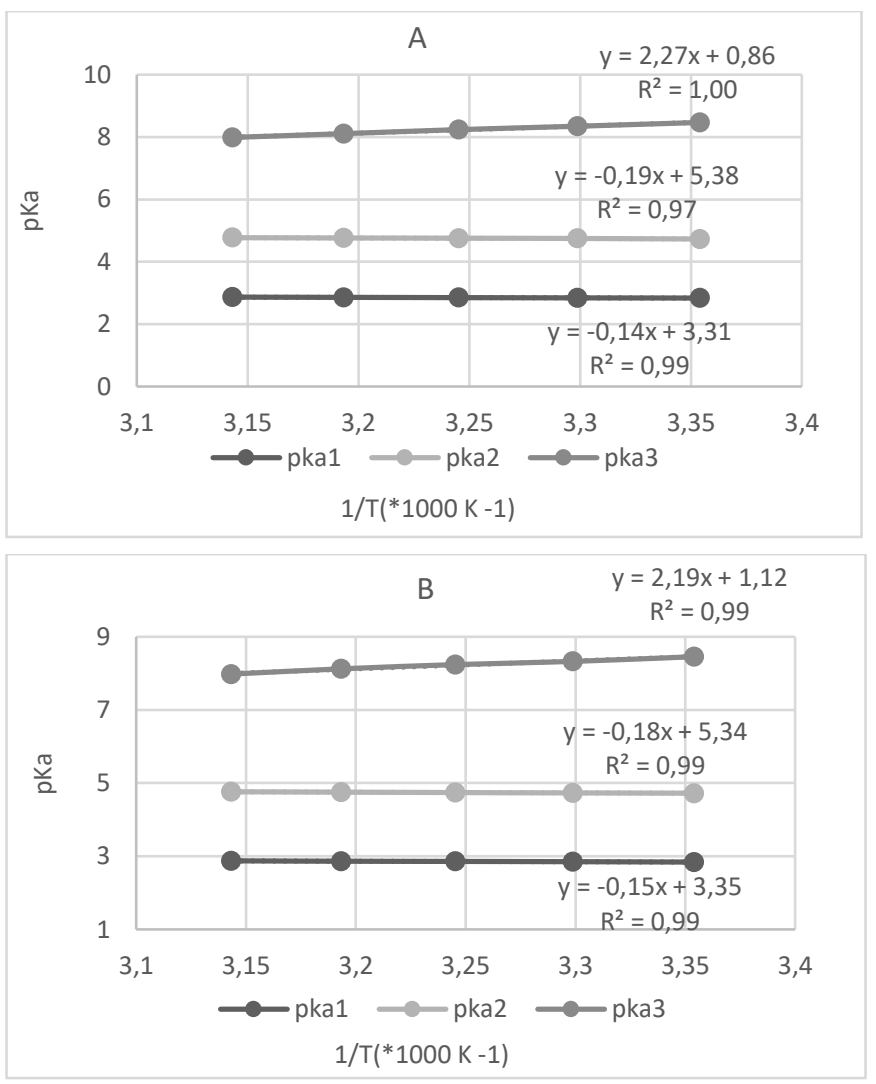

Figure 6. The plotting of calculated (A) and experimentally determined (B) pKa versus 1/T for GLY-ASP.

In order to calculate $\Delta \mathrm{H}$ and $\Delta \mathrm{S}$, the $\mathrm{pK}_{\mathrm{a}}$ values, at the different temperature $\mathrm{T}$ $=298.15 \mathrm{~K}, 303.15 \mathrm{~K}, 308.15 \mathrm{~K}, 313.15 \mathrm{~K}$, and $318.15 \mathrm{~K}$, were plotted versus $1 / \mathrm{T}$ by using Eq. (31) (Figure 6). The experimentally determined and theoretically calculated values of changes of Gibbs free energy, enthalpy, and entropy for GLY-ASP are listed in Table 6 . According to this table, $\Delta \mathrm{G}$ increases with temperature increase, $\Delta \mathrm{S}$ is negative, and $\Delta \mathrm{H}$ is negative during the first and second ionization but positive for the third ionization. As a result, the first and second ionization reactions of GLY-ASP are spontaneous at low temperature. 
Table 6. The experimentally determined and theoretically calculated values of changes of Gibbs free energy, enthalpy, and entropy for GLY-ASP

\begin{tabular}{|c|c|c|c|c|c|c|c|}
\hline \multirow{2}{*}{ Specie } & \multirow{2}{*}{$\Delta \mathrm{H}(\mathrm{kJ} / \mathrm{mol})$} & \multirow{2}{*}{$\Delta \mathrm{S}(\mathrm{J} / \mathbf{m o l . K})$} & \multicolumn{5}{|c|}{$\Delta G(\mathrm{~kJ} / \mathrm{mol})$} \\
\hline & & & $298.15 \mathrm{~K}$ & 303.15 K & 308.15 K & 313.15 K & $318.15 \mathrm{~K}$ \\
\hline \multirow{8}{*}{ GLY-ASP } & \multicolumn{7}{|c|}{ Exp. } \\
\hline & -2.73 & -63.45 & 16.18 & 16.50 & 16.82 & 17.14 & 17.45 \\
\hline & -3.68 & -102.96 & 27.01 & 27.53 & 28.04 & 28.56 & 29.07 \\
\hline & 43.47 & -16.37 & 48.35 & 48.44 & 48.52 & 48.60 & 48.68 \\
\hline & \multicolumn{7}{|c|}{ Cal. } \\
\hline & -2.89 & -64.1 & 16.22 & 16.54 & 16.86 & 17.18 & 17.50 \\
\hline & -3.54 & -102.28 & 26.95 & 27.46 & 27.98 & 28.49 & 29.00 \\
\hline & 41.86 & -21.52 & 48.28 & 48.39 & 48.49 & 48.60 & 48.71 \\
\hline
\end{tabular}

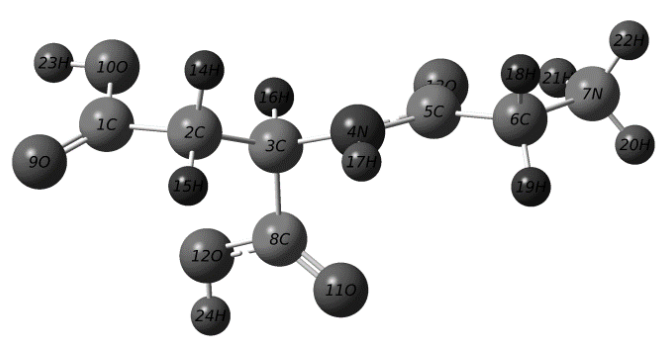

A: $\left(\mathrm{H}_{3} \mathrm{~L}^{+}\right)$

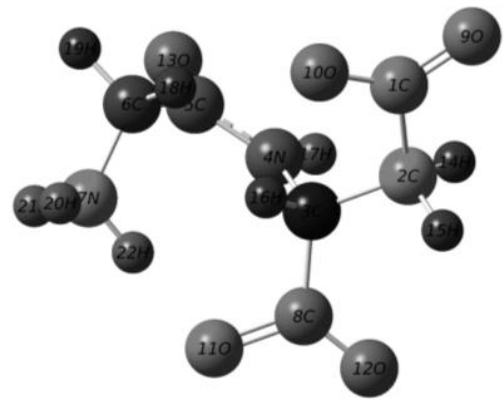

C: $\left(\mathrm{HL}^{-}\right)$

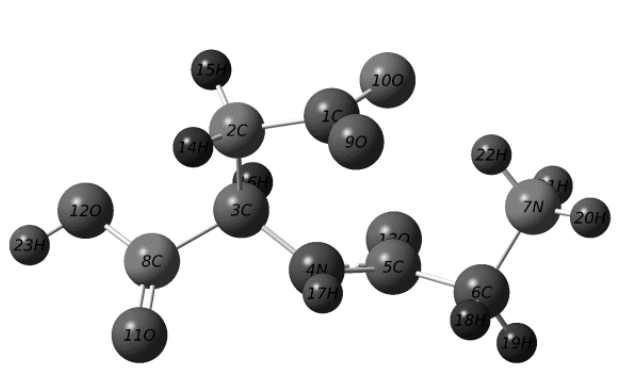

B: $\left(\mathrm{H}_{2} \mathrm{~L}\right)$

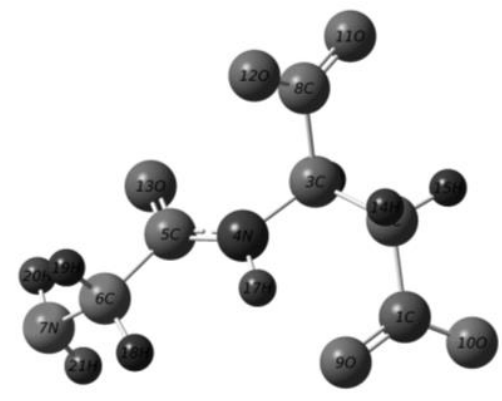

D: $\left(\mathrm{L}^{2-}\right)$

Figure 7. The natural atomic charge distribution for different species of GLY-ASP at $\mathrm{T}=298.15 \mathrm{~K}$ (cation, neutral, anion) with color range.

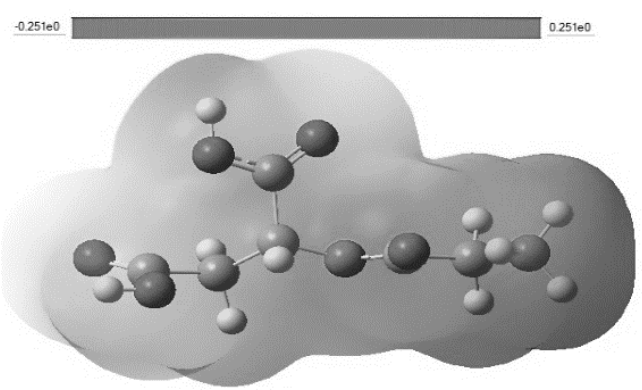

A: $\left(H_{3} L^{+}\right)$

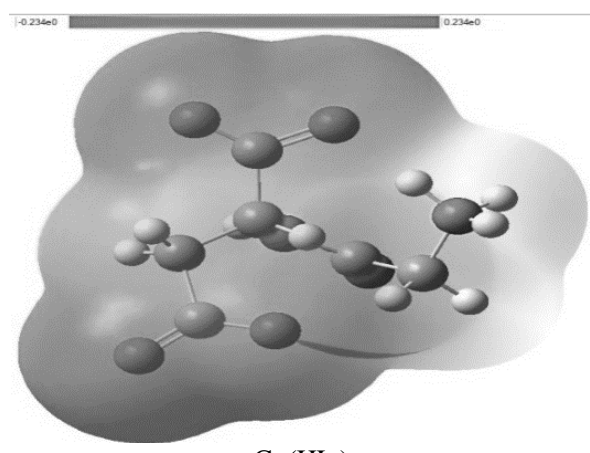

C: $\left(\mathrm{HL}^{-}\right)$

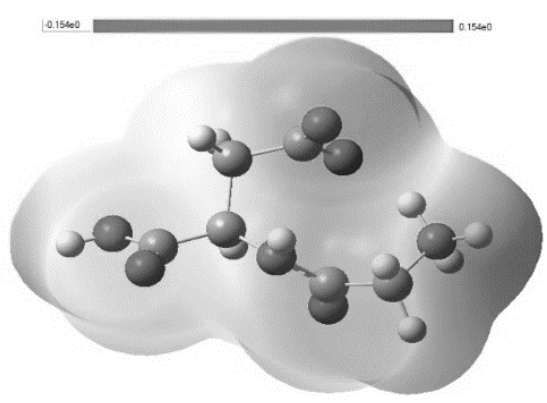

B: $\left(\mathrm{H}_{2} \mathrm{~L}\right)$

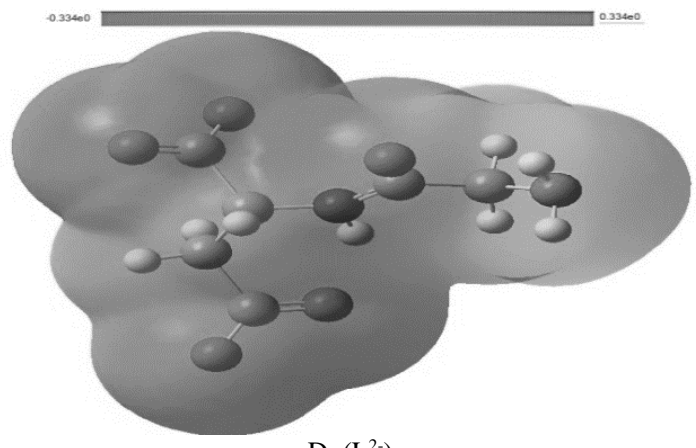

D: $\left(\mathrm{L}^{2-}\right)$

Figure 8. The total electron density isosurface mapped with the molecular electrostatic potential (MEP) for different species of GLY-ASP at T = 298.15 K. (red: O; blue: $\mathrm{N}$; gray: $\mathrm{C}$; white: $\mathrm{H}$ ). 


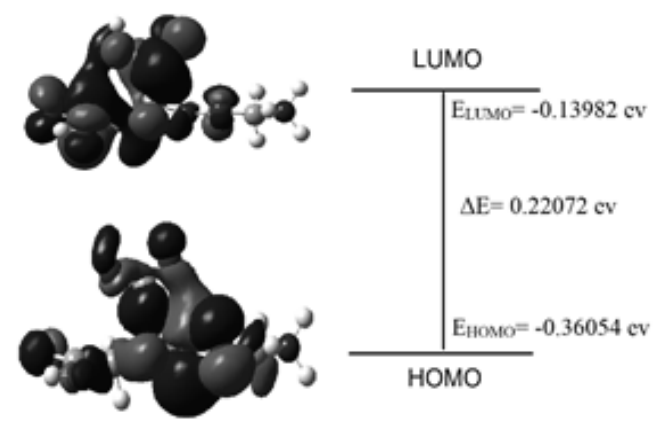

A: $\left(\mathrm{H}_{3} \mathrm{~L}^{+}\right)$

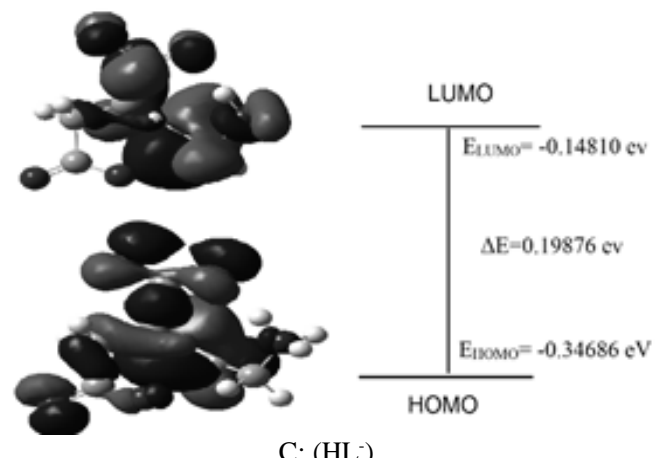

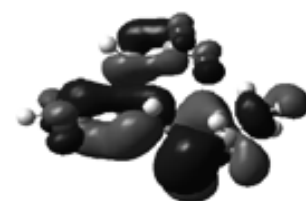
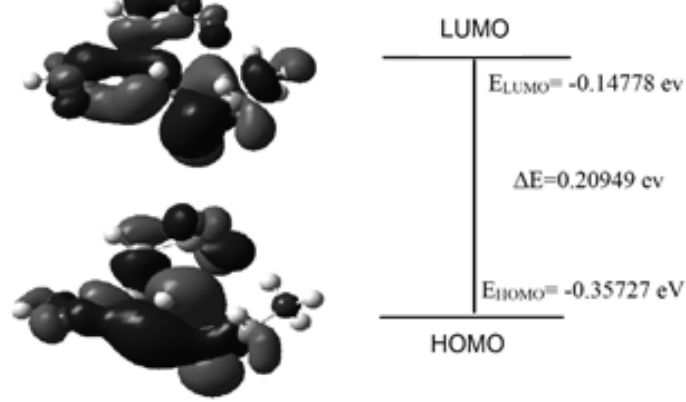

$\Delta \mathrm{E}=0.20949 \mathrm{cv}$

$E_{110 \mathrm{Mo}}=-0.35727 \mathrm{eV}$

HOMO

B: $\left(\mathrm{H}_{2} \mathrm{~L}\right)$

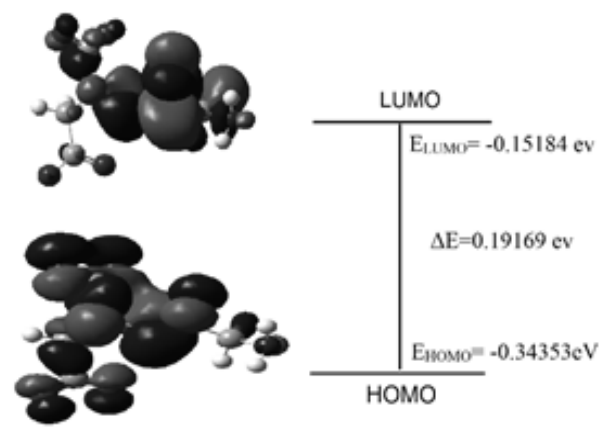

D: $\left(\mathrm{L}^{2-}\right)$

Figure 9. The atomic orbital compositions of the frontier molecular orbitals for different species of GLY-ASP at T = 298.15 K. (cationic, neutral, anionic) (red: O; blue: N; gray: C; white: H) (color figure online).

\section{MULLIKEN ATOMIC CHARGES}

Flux distribution is one of the important factors in molecules. Figure 7 shows the flux distribution of all GLY-ASP species at $298.15 \mathrm{~K}$. It shows that the atoms $\mathrm{C}_{1}, \mathrm{C}_{5}$, and $\mathrm{C}_{8}$ have more positive charge among carbon atoms of various species of GLY-ASP. As can be seen in Figure 7, the oxygen atoms are attached to $C_{1}$, $\mathrm{C}_{5}$, and $\mathrm{C}_{8}$. It is well known that the oxygen atom has high electronegativity. In addition, the atoms $\mathrm{N}_{7}, \mathrm{O}_{10}$, and $\mathrm{O}_{12}$, compared to other atoms, have more negative charge.

Figure 8 shows the electrostatic-molecular potential distribution of molecular (MEP) charge in 3D for different species of GLY-ASP at T $=298.15 \mathrm{~K}$. The charged areas of the molecule can also be seen in this figure. In a molecule, the information obtained from charge distribution can be applied to describe the reaction between various species. MEP has resulted in the correlation of electronic charges of nuclear and electrons of molecules. Therefore, it gives us useful data to detect various species [45]. MEP has a specific role in the determination of charged molecule areas with neighboring molecules. Actually, these reactive sites are useful in prediction of the reaction between one electrophile and one nucleophile. Various areas of MEP are detected with colors like red, orange, yellow, green, and blue [46]. The negative values (red) in MEP are related to the reactivity of electrophile and the positive areas (blue) are related to nucleophile reactivity [46]. There are several sites for electrophiles to attack oxygen atom in GLY-ASP. In addition, areas with positive charge are usually placed on hydrogen atom. This shows the probability of nucleophile attack on these sites.

\section{HOMO AND LUMO}

Energy gap is the gap between the highest full level in the HOMO (or halfoccupied molecular orbital) capacity bar and the lowest empty level in the LUMO conduction bar. HOMO and LUMO are the most important orbitals in a molecule. They are called border molecular orbitals. Examination of border molecular orbitals has a determining role in the chemical stability of molecules. HOMO and LUMO energy estimate the reduction or oxidation characteristics of a molecule [48]. The energy gap between HOMO and LUMO determines the optical reactivity and chemical hardness and softness of the molecule. Energy gap or energy difference between HOMO and LUMO levels is an important stability index for structures. The high difference between these two levels
(HOMO and LUMO) shows a high stability. Also, the smaller HOMO-LUMO energy gap indicates that the molecule is the more reactive and more polarizable [49]. High stability of a molecule means low reactivity in chemical reactions.

Based on the provided data in Table 7 (The values of $\Delta \mathrm{E}$ and $\mathrm{E}_{\mathrm{Gap}}$ ), and according to the energy difference between species, it can be stated that the specie $\mathrm{L}^{2-}$ has high reactivity. According to Figure 9, HOMO focuses more on carboxyl group and LUMO focuses on the $\mathrm{NH}_{3}$ of a molecule. It can be seen in Table 7 that differences of energy level $(\Delta \mathrm{E})$ for GLY-ASP decrease with increasing of negative charge.

Table 7. Calculated chemical reactivity for different species of GLY-ASP at $\mathrm{T}=298.15 \mathrm{~K}$. (cation, neutral, anion).

\begin{tabular}{|l|c|c|c|c|}
\hline Parameters & $\mathbf{H}_{\mathbf{3}} \mathbf{L}^{+}$ & $\mathbf{H}_{\mathbf{2}} \mathbf{L}$ & $\mathbf{H L}^{-}$ & $\mathbf{L}^{\mathbf{2}}$ \\
\hline $\mathrm{E}_{\mathrm{LUMO}}$ & -0.14 & -0.15 & -0.15 & -0.15 \\
\hline $\mathrm{E}_{\text {HOMO }}$ & -0.36 & -0.36 & -0.35 & -0.34 \\
\hline $\mathrm{A}$ & 0.14 & 0.15 & 0.15 & 0.15 \\
\hline $\mathrm{I}$ & 0.36 & 0.367 & 0.35 & 0.34 \\
\hline$\Delta \mathrm{E}$ & 0.22 & 0.21 & 0.20 & 0.19 \\
\hline $\mathrm{E}_{\text {Gap }}$ & 6.01 & 5.70 & 5.41 & 5.22 \\
\hline
\end{tabular}

\section{CONCLUSION}

In this research work, the acid dissociation constants of GLY-ASP were experimentally determined and theoretically calculated at various temperatures, $\mathrm{T}=(298.15,303.15,308.15,313.15,318.15) \mathrm{K}$. In calculation section, ab initio and DFT methods were used based on the B3LYP/6-31+G(d) theory. Also, Thomasi's method was used to analyze the formation of intermolecular hydrogen bonds between the water molecule and various species of GLY-ASP. In experimental section, the potentiometric titration technique was used to obtain $\mathrm{pK}_{\mathrm{a}}, \mathrm{s}$ values.

We compared the experimentally determined and theoretically calculated $\mathrm{pK}_{\mathrm{a}}$ values of GLY-ASP at different temperatures and good agreements were observed for them. It was observed that $\mathrm{pK}_{\mathrm{a} 1}$ and $\mathrm{pK}_{\mathrm{a} 2}$ increase and $\mathrm{pK}_{\mathrm{a} 3}$ decreases by temperature growth. The values of $\Delta \mathrm{H}$ and $\Delta \mathrm{S}$ were obtained using Van't Hoff eq (plotting $\mathrm{pK}_{\mathrm{a}}$ versus $1 / \mathrm{T}$ ). The values of $\Delta \mathrm{G}$ were calculated using values of $\Delta \mathrm{H}, \Delta \mathrm{S}$, and $\mathrm{T}$. The results show that $\Delta \mathrm{G}$ values increase with temperature growth. $\Delta \mathrm{S}$ has negative values in first, second and third processes 
of ionization of GLY-ASP. In addition, $\Delta \mathrm{H}$ has negative values in first and second ionization processes and positive values for the third ionization process. Finally, the theoretical calculations of the HOMO-LUMO gap for GLY-ASP show that the negative charges increase in lower potential.

\section{CONFLICT OF INTEREST}

The authors declare that they have no conflict of interest.

\section{REFERENCES}

1. M.D. Beachy, D, Chasman, R.B. Murphy, T.A. Halgren, R.A. Friesner, Accurate ab initio quantum chemical determination of the relative energetics of peptide conformations and asseessment of empirical force fields., J. Am. Chem. Soc. 119 (1997) 5908-5920.

2. M. Kanost, J.K. Kawooya, J.H. Law, R.O. Ryan, M.C. Van Heusden, R. Ziegler, Insect hemolymph proteins, Advances in Insect Physiology. 22 (1990) 299-396

3. P.D. Bailey, an Introduction to peptide chemistry, John Wiley and Sons. 1992, New York.

4. A. Catsch, A.E. Harmuth-Hoene, Pharmacology and therapeutic applications of agents used in heavy metal poisoning. Pharmacol. Ther. 1 (1976) 1-118.

5. M. Monajjemi, F. Gharib, H. Aghaei, G. Shafiee, A. Thghvamanesh, A. Shamel, Thallium (I) complexes of some sulfur containing ligands. Main Group Met. Chem. 26 (2003) 39-47.

6. Ju. Lurie, Handbook of Analytical Chemistry, 1st ed.; Mir: Moscow, 1975.

7. Thomas, G. Medicinal Chemistry: An Introduction; John Wiley and Sons: West Sussex 2000.

8. W. Stumm, J.J. Morgan, Aquatic Chemistry: Chemical Equilibria and Rates in Natural Waters; Wiley-Interscience. 1996, New York.

9. H. Wan, J. Ulander, High-throughput $\mathrm{pK}_{\mathrm{a}}$ screening and prediction amenable for ADME profiling. Expert. Drug. Metab. Toxicol. 2 (2006) 139-155.

10. A. Albert, The determination of ionization constants. a laboratory manual Springer, New York City, 2012.

11. S. Sharifi, D. Nori-shargh, A. Bahadory, Complexes of Thallium (I) and Cadmium (II) with Dipeptides of L-phenylalanylglycine and Glycyl-Lphenylalanine. J. Braz. Chem. Soc. 18 (2007) 1011-1016.

12. P. Janos, Determination of equilibrium constants from chromatographic and electrophoretic measurements. J. Chromatogr. A. 1037 (2004) 15-28.

13. A. Avdeef, J.E. Comer, S.J. Thomson, pH-Metric log P. 3. Glass electrode calibration in methanol-water, applied to $\mathrm{pK}_{\mathrm{a}}$ determination of waterinsoluble substances. Anal. Chem. 65 (1993) 42-49.

14. K.Y. Tam, K. Takacs-Novak, Multi-wavelength spectrophotometric determination of acid dissociation constants: a validation study. Anal. Chim. Acta. 434 (2001) 157-167.

15. J. Wang, Analytical electrochemistry (3rd ed) John Wiley \& Sons. New York: John Wiley \& Sons. 2006.

16. K. Mohle, H.J. Hofmann, Stability order of basic peptide conformations reflected by density functional theory. J. Mol. Model. 4 (1998) 53-60.

17. S.J. Archer, P.J. Domaille, E.D. Laue, New NMR methods for structural studies of proteins to aid in drug design. Ann. Rep. Med. Chem. 31 (1996) 299-307.

18. B.J. Smith, L. Radom, Evaluation of accurate gas-phase acidities. J. Phys. Chem. 95 (1991) 10549-10551.

19. D.D. Perrin, B. Dempsey, E.P. Serjeant, pKa Prediction for organic acids and bases. London: Chapman \& Hall. pp. 21-26, 1981.

20. R. Gomes-Bombarelli, M. Gonzalez-Perez, M.T. Perez-Prior, E. Calle, J. Casado, Computational Study of Eseters and Lactones. A Case Study of Diketenese. J. Org. Chem. 74 (2009) 4943-4948.

21. M. Alimohammady, M. Jahangiri, F. Kiani, H. Tahermansouri, Molecular modeling, pKa and thermodynamic values of asthma drugs. Med. Chem. Res. 27 (2017) 95-114.

22. C. Lee, W. Yang, R.G. Parr, Development of the Colle-Salvetti correlationenergy formula into a functional of the electron density. Phys. Rev. B. 37 (1988) 785-789.

23. A.D. Becke, Density-functional thermochemistry. III. The role of exact exchange. J. Chem. Phys. 98 (1993) 5648-5652.

24. M.J. Frisch, G.W. Trucks, H.B. Schlegel, G.E. Scuseria, Gaussian 98, Revision A.6, Gaussian, Inc., Pittsburgh, PA, 1998

25. S. Miertus, E.J. Tomasi, Approximate evaluations of the electrostaticfree energy and internal energy changes in solution processes. Chem. Phys. 65 (1982) 239-245

26. S. Miertus, E. Scrocco, J. Tomasi, Electrostatic interaction of a solute with a continuum. A direct utilizaion of $\mathrm{AB}$ initio molecular potentials for the prevision of solvent effects. Chem. Phys. 55 (1981) 117-129.
27. R. Cammi, J. Tomasi, Remarks on the use of the apparent surface charges (ASC) methods in solvation problems: Iterative versus matrix-inversion procedures and the renormalization of the apparent charges. J. Comput. Chem. 16 (1995) 1449-1458.

28. M.T. Beck, I. Nagypal, Chemistry of Complex Equilibria. Ellis Harwood, 1990, New York

29. E. Kilic, N. Aslan, Determination of autoprotolysis constants of waterorganic solvent mixtures by potentiometry. Microchim. Acta. 151 (2005) 89-92.

30. A. Farajtabar, F. Naderi, F. Gharib, Autoprotolysis in water/methanol/NaCl ternary systems. J. Serb. Chem. Soc. 78 (2013) 1561-1567.

31.N. Maleki, B. Haghighi, A. Safavi, Evaluation of formation constants, molar absorptivities of metal complexes, and protonation constants of acids by nonlinear curve fitting using microsoft excel solver and user-defined function. Microchem. J. 62 (1999) 229-236.

32. J.A. Dean, Lange's Handbook of Chemistry, 15th Ed.; McGraw-Hill. 1999, New York.

33. H.A. Laitinen, W.E. Harris, Chemical Analysis; McGraw-Hill. 1975, New York

34. P.W. Atkins, Physical Chemistry, 6th ed.; Oxford University Press. 1998, England.

35. Jeffrey, G.A. an Introduction to Hydrogen Bonding, Oxford University Press. 1997, Oxford.

36. Y. Marcus, The properties of organic liquids that are relevant to their use as solvating solvents. Chem. Soc. Rev. 22 (1993) 409-416.

37. F. Kiani, S.B. Hosseini, S.A. Shahidi, F. Koohyar, Ab initio and DFT studies on ionization of saccharin in aqueous solution. Chemistry Today 34 (2016) 26-29.

38. A. Nag, B. Dey, Computer-aided drug design and delivery systems, 1976.

39. J.B. Chaires, Calorimetry and thermodynamics in drug design. Annu. Rev. Biophys. 37 (2008) 135-151.

40. A.J. Ruben, Y. Kiso, E. Freire, Overcoming roadblocks in lead optimization: a thermodynamic perspective. Chem. Biol. Drug. Des. 67 (2006) 2-4.

41. B.K. Shukla, U. Yadava, M. Roychoudhury, Theoretical explorations on the molecular structure and IR frequencies of 3- phenyl-1-tosyl-1H-pyrazolo [3, 4-d] pyrimidin-4-amine in view of experimental results. J. Mol. Liq. 212 (2015) 325-330

42. M. Ogurlu, Adsorption of a textile dye onto activated sepiolite, J. Microporous and Mesoporous Materials. 119 (2009) 276-283.

43. Y.D. Arzu, A comparative study on determination of the equilibrium, kinetic and thermodynamic parameters of biosorption of copper(II) and lead (II) ions onto pretreated Aspergillusniger, J. Biochem. Eng. 28 (2006) 187-195.

44.P.M. Pimentel, M.A.F. Melo, D.M.A. Melo, A.L.C. Assuncao, D.M Henrique, J.r C.N, Siva, G. Gonzalez, Kinetics and thermodynamics of $\mathrm{Cu}$ (II) adsorption on oil shale wastes, J. Fuel Processing Technology. 89 (2008) 62-67.

45. J.A. Mondragon-Sanchez, R. Santamaria, R. Garduno-Juarez, Docking on the DNA G-quadruplex: A molecular electrostaticpotential study. Biopolymers. 95 (2011) 641-650.

46. P. Politzer, D.G. Truhlar, Chemical Applications of Atomic and Molecular Electrostatic Potentials: Reactivity, Structure, Scattering,and Energetics of Organic, Inorganic, and Biological Systems.Springer Science \& Business Media, Berlin/Heidelberg, Germany, 2013.

47. R.H. Petrucci, W.S. Harwood, F.G. Herring, J.D. Madura, General Chemistry: Principles \& Modern Applications. 9th Ed. New Jersey: Pearson Education, Inc, 2007.

48. T. Nogrady, D.F. Weaver, Medicinal Chemistry: A Molecular and Biochemical Approach. Oxford University Press, USA, 2005.

49. A. Asghar, A. Aziz Abdul Raman, W.M.A. Wan Daud, A. Ramalingam, Reactivity, stability, and thermodynamic feasibility of $\mathrm{H}_{2} \mathrm{O}_{2} / \mathrm{H}_{2} \mathrm{O}$ at graphite cathode: application of quantum chemical calculations in MFCs. American Institute of Chemical Engineers, DOI 10.1002/ep.12806, 2017. 